\title{
HAND-ASSISTED LAPAROSCOPIC OVARIOHYSTERECTOMY IN THE MARE
}

\author{
by \\ Uta Delling \\ Thesis submitted to the faculty of the \\ Virginia Polytechnic Institute and State University \\ in partial fulfillment of the requirement for the degree of \\ MASTER OF SCIENCE \\ in \\ Veterinary Medical Sciences
}

R. SCOTT PLEASANT, Chairman

RICK D. HOWARD, Co-Chair

OTTO I. LANZ

May 09, 2005

Blacksburg, Virginia

KEYWORDS: Ovariohysterectomy, hand-assisted laparoscopic surgery, equine 


\title{
HAND-ASSISTED LAPAROSCOPIC OVARIOHYSTERECTOMY IN THE MARE
}

\author{
Uta Delling
}

\section{(ABSTRACT)}

Conventionally performed equine ovariohysterectomy (OHE) is a technically demanding surgery associated with a high degree of invasiveness and morbidity. Handassisted laparoscopic surgical technique allows introduction of a hand through a portal into the laparoscopic field to facilitate surgical manipulation while maintaining abdominal insufflation and laparoscopic visualization. The purpose of this study was to develop and evaluate a hand-assisted laparoscopic OHE technique for dorsally recumbent horses.

The surgical technique was developed in terminal (2 mares) and subsequently evaluated in 6 survival procedures. Mares were fasted 48 hours, anesthetized and positioned in dorsal recumbency for laparoscopic surgery. A hand access device (Omniport) was placed in a caudal midline laparotomy followed by 4 laparoscopic portals. Transection of the ovarian pedicle and broad ligament was achieved using a combination of a laparoscopic stapling instrument, an ultrasonically activated instrument and endoscopic clips. The genital tract was exteriorized through the laparotomy, and the body of the uterus transected and sutured in conventional pattern. Horses were evaluated through postoperative day 14 when a post mortem evaluation was performed.

Four mares recuperated well after surgery, 1 mare was euthanized due to bilateral femur fractures sustained during anesthetic recovery and another developed severe pleuropneumonia. At necropsy all but one abdominal incision was healing routinely. One mare had abscessed along the laparotomy incision and developed visceral adhesions. Uncomplicated healing of transected mesovarial, mesometrial and uterine remnants was observed in all recovered mares.

Hand-assisted laparoscopic OHE technique represents a minimally invasive and technically feasible alternative for conventional OHE. Careful patient selection and preparation may reduce the complications observed in this study. 


\section{ACKNOWLEDGEMENTS}

I would like to thank both my mentors, Dr. Rick D. Howard and Dr. R. Scott Pleasant, for their guidance, advice and encouragement during this project and my entire time at the Virginia-Maryland Regional College of Veterinary Medicine in Blacksburg. I would also like to thank he other member of my graduate committee, Dr. Otto Lanz, for his contribution and counsel on my research.

I wish to thank Dr. Katja F. Düsterdieck and Dr. Douglass B. Berry II for their help and support during the practical part of my project. A special hanks to Tony Huffman and Teresa Ward and many other technicians at the Large Animal Clinic, and the many senior veterinary students, whose help I very much appreciated.

I am especially grateful to Terry Lawrence for the excellent illustrations of the surgical procedure and Jerry Baber for the photographs.

The Omniport devices used during the study were provided by Mr. Rick Filer of Weck $^{\circledR}$, Research Triangle Park, NC.

This project was supported in part by the Patricia Bonsall Stuart Award for Equine Studies. 


\section{TABLE OF CONTENTS}

ABSTRACT

ACKNOWLEDGMENTS iii

TABLE OF CONTENTS iv

LIST OF FIGURES vi vi

LIST OF TABLES vii

LIST OF ABBREVIATIONS viii

1. INTRODUCTION 1

2. OBJECTIVES AND HYPOTHESIS 3

3. LITERATURE REVIEW 4

3.1. Ovariohysterectomy in the mare 4

3.1.1. Indications for ovariohysterectomy 4

3.1.2. Conventional technique for ovariohysterectomy 4

3.2. Laparoscopic techniques 6

3.2.1. General aspects of laparoscopic techniques 6

3.2.2. Hemostasis during laparoscopic ovariectomy in the mare 6

3.2.2.1. Technical aspects of the Harmonic Scalpel 8

3.2.3. Laparoscopic ovariohysterectomy (L-OHE) and laparoscopic hysterectomy (L-HE) in other species 8 
3.2.4. Hand-assisted laparoscopic surgery in human medicine 10

3.2.5. Hand-assisted laparoscopic surgery in veterinary medicine 13

3.3. Anatomical aspects related to the female urogenital tract in the horse

3.3.1. Female equine urogenital tract 13

3.3.2. Blood supply to the urogenital tract 14

4. MATERIAL AND METHODS 16

4.1. Animals used during the study 16

$\begin{array}{ll}\text { 4.2. Presurgical preparation } & 16\end{array}$

$\begin{array}{ll}\text { 4.3. } & \text { Surgical procedure }\end{array}$

$\begin{array}{lll}\text { 4.4. Post surgical management } & 20\end{array}$

4.5. Post mortem evaluation 20

5. RESULTS 21

$\begin{array}{lll}\text { 5.1. Intraoperative Findings } & 21\end{array}$

5.2. Postoperative Findings 22

5.3. Necropsy Findings 23

$\begin{array}{ll}\text { 6. DISCUSSION } & 25\end{array}$

7. CONCLUSION 33

8. BIBLIOGRAPHY 34

9. APPENDIX 44

$\begin{array}{ll}\text { 10.VITA } & 71\end{array}$ 


\section{LIST OF FIGURES}

$\begin{array}{lll}\text { Figure } 1 . \quad \text { Omniport } & 44\end{array}$

Figure 2. Insertion of the Omniport 45

Figure 3. Hand placement through the Omniport 46

Figure 4. Location of the celiotomy and the laparoscopic portals 47

Figure 5. Application of the laparoscopic stapling instrument 48

Figure 6. Application of the Harmonic Scalpel 49

Figure 7. Application of the endoscopic clips 50

$\begin{array}{lll}\text { Figure 8. } & \text { Exteriorized genital tract } & 51\end{array}$

Figure 9. Closure of the uterine stump 52

Figure 10. Completed closure 53 


\section{LIST OF TABLES}

Table 2-1. Advantages and disadvantages of HALS technique vs. standard laparoscopy

Table 8-1. Anamnesis of the experimental horses

Table 8-2. Preoperative complete blood count values of the experimental horses

Table 8-3. Preoperative clinical blood chemistry values of the experimental horses

Table 8-4. Anesthetic aspects and parameters of the experimental horses

Table 8-5. Surgical aspects and parameters of the experimental horses

Table 8-6. Wound healing and other postoperative findings of the experimental horses

Table 8-7. Preoperative and postoperative pulse rate values of the experimental horses

Table 8-8. Preoperative and postoperative respiration rate values of the experimental horses

Table 8-9. Preoperative and postoperative body temperature values of the experimental horses

Table 8-10. Preoperative and postoperative general attitudes of the experimental horses

Table 8-11. Preoperative and postoperative borborygmi of the experimental horses

Table 8-12. Preoperative and postoperative appetite of the experimental horses

Table 8-13. Preoperative and postoperative packed cell volume and total protein values of the experimental horses

Table 8-14. Macroscopic post mortem findings of the experimental horses 


\section{LIST OF ABBREVIATIONS}

\begin{tabular}{|c|c|}
\hline BAR & bright, alert, and responsive \\
\hline BID & twice daily \\
\hline $\mathrm{cm}$ & centimeter \\
\hline $\mathrm{CO}_{2}$ & carbon dioxide \\
\hline$d$ & day \\
\hline decr. & decreased \\
\hline depr. & depressed \\
\hline${ }^{\circ} \mathrm{F}$ & degree Fahrenheit \\
\hline Fig. & figure \\
\hline HALS & hand-assisted laparoscopic surgery \\
\hline $\mathrm{IM}$ & intramuscularly \\
\hline IU & international units \\
\hline IV & intravenous \\
\hline $\mathrm{kg}$ & kilogram \\
\hline MAP & mean arterial pressure \\
\hline $\mathrm{mg}$ & milligram \\
\hline $\min$ & minute \\
\hline $\mathrm{ml}$ & milliliter \\
\hline $\mathrm{mm}$ & millimeter \\
\hline $\mathrm{mmHg}$ & millimeter of mercury \\
\hline $\mathrm{N} / \mathrm{A}$ & not applicable \\
\hline NAF & no abnormal findings \\
\hline$N / E$ & not evaluated \\
\hline no. & number \\
\hline $\mathrm{OHE}$ & ovariohysterectomy \\
\hline PCV & packed cell volume \\
\hline post op & postoperative \\
\hline QAR & quite, alert, responsive \\
\hline
\end{tabular}




\section{LIST OF ABBREVIATIONS cont.}

$\begin{array}{ll}\text { QH } & \text { Quarter Horse } \\ \text { TB } & \text { Thoroughbred } \\ \text { TP } & \text { total protein } \\ \text { qd } & \text { once a day } \\ \text { vs. } & \text { versus } \\ \mu g & \text { microgram } \\ \# & \text { number }\end{array}$




\section{INTRODUCTION}

In small animal practice, ovariohysterectomy (OHE) is the most commonly performed surgical procedure (Blomberg 1996). Indications for this surgery are less frequent in horses. Treatment of chronic pyometra, tumor removal and congenital abnormalities represent the majority of abnormalities requiring OHE in the mare (Slone 1988, Broome et al. 1992, Santschi et al. 1995, Rötting et al. 2003).

Traditionally, OHE in the mare has been performed through a ventral midline celiotomy. The pedicle of the ovaries and the broad ligaments are severed and the genital tract transected as caudal as possible. The large size of the equine abdomen and the deep location of the genital tract renders access and manipulation of the ovaries and uterus a challenge for the equine surgeon. Furthermore, the large incision required to gain access to the caudal uterus, the nvasive nature of the procedure as well as the complexity of the underlying diseases are associated with a significant degree of postoperative morbidity and even mortality in these mares (Slone 1988, Santschi et al. 1995, Rötting et al. 2003).

Minimal invasive surgical techniques are commonly used in human and veterinary medicine, either as diagnostic tool or as a therapeutic access mode (Walmsley 1999, Neudecker et al. 2002). In horses, laparoscopy has been described with the recognized advantages of increased intraoperative visualization, smaller incisions, less extensive manipulation of the abdominal viscera, reduced postoperative pain and reduced periods of convalescence compared with corresponding procedures performed using conventional methods (Walmsley 1999, Klohnen 2002). Laparoscopic OHE in dogs has been associated with less postoperative pain compared to conventional performed OHE (Davidson et al. 2004).

A recent advance in human laparoscopic surgery has been the development of hand-assisted laparoscopic surgery (HALS), a technique where the surgeon's hand can be inserted into the laparoscopic field while maintaining laparoscopic visualization (Wolf 
2001, McGinnis et al. 2001). The hand is either introduced through a mini-laparotomy alone or through a special hand port device, which allows a seal between the surgeon's arm and the device, thus maintaining abdominal insufflation.

Technically complex laparoscopic procedures have been facilitated using HALS by the coordinate manual manipulation and retraction of tissues and manipulations of transabdominally placed instruments (Pelosi and Pelosi 1999, Freeman and Gallagher 2002). Additionally, large specimens can be removed from the abdomen through the device (Romanelli et al. 2001). Hand-assisted laparoscopic surgery combines the convenience and safety of conventional open surgical techniques with the advantages of minimally invasive surgery (Meijer et al. 2000).

The aim of this study was, to develop a hand assisted laparoscopic OHE technique in the mare and evaluate the safety and complications associated with the method. 


\section{OBJECTIVES AND HYPOTHESIS}

Objectives of the study:

I) To develop a minimally invasive, hand-assisted laparoscopic ovariohysterectomy technique for horses.

II) Evaluate the safety and complications associated with the method.

Hypothesis

We hypothesized that a hand-assisted laparoscopic technique can be used for $\mathrm{OHE}$ in the mare. 


\section{LITERATURE REVIEW}

\subsection{Ovariohysterectomy in the mare}

\subsubsection{Indications for ovariohysterectomy}

Ovariohysterectomy is most commonly utilized for the treatment of chronic pyometra non-responsive to medical management (Slone 1988, Santschi et al. 1995, Rötting et al. 2003). Pyometra in the mare has been defined as accumulation of pus in the uterus. Physical or functional outflow obstruction may be responsible for the condition, but in certain cases no lesion can be demonstrated and the cause of the problem remains unexplained (Asbury and Lyle 1993). Retention of fetal remnants can cause pyometra and may require OHE (Santschi et al. 1995). Other indications for OHE in horses include the removal of uterine neoplasia. Uterine leiomyoma (Romagnoli et al. 1987, Santschi and Slone 1994, Berezowski 2002), fibroleiomyoma (Romagnoli et al. 1987, Broome et al. 1992), leiomyosarcoma (Santschi et al. 1995), as well as a botryoid rhabdomyosarcoma (Torbeck et al. 1980) have been treated by total or partial OHE. Congenital abnormalities, like segmental aplasia of the cervix with mucometra, also may justify removal of the uterus (Vaughan 1986). Horses with chronic uterine hematoma of unknown origin have been treated by OHE Rötting et al. 2003). Recently, 2 cases of chronic uterine torsion requiring OHE have been described (Doyle et al. 2002).

\subsubsection{Conventional technique for ovariohysterectomy}

The conventional technique for OHE in the horse is via caudal ventral midline celiotomy (Slone 1988, Broome et al. 1992, Santschi et al. 1995). Extending from the pubis cranial, up to $40 \mathrm{~cm}$ incisional length is generally necessary (Santschi et al. 1995). Other authors recommend division of the mammary gland to gain maximal access to the caudal aspect of the genital tract (Slone 1988, Rötting et al. 2003). Manual retraction of the abdominal wall and intestine, tilting the surgical table to place the horse in a head down position, or exteriorization of the large colon during resection may be required to improve surgical access and visualization (Santschi et al. 1995, Rötting et al. 2003). 
Exposure of the caudal reproductive tract was judged to be limited (Santschi et al. 1995), and technically difficult (Rötting et al. 2003).

Several methods are available for achieving hemostasis of the ovarian and uterine arteries. Ligation of the ovarian pedicle with suture material followed by sharp transection is he most commonly employed method (Slone 1988, Broome et al. 1992, Santschi et al. 1995, Rötting et al. 2003). Additional methods include the employment of a chain ecraseur (Hooper et al. 1992), Serra emasculator (Rötting et al. 2003) or an automatic stapling instrument (TA Premium 90) (Santschi and Slone 1994, Santschi et al. 1995). Use of a stapling instrument was described after failure of a ligature to provide sufficient hemostasis in one report (Broome et al. 1992). Vessels of the mesometrium have been occluded with suture material during sharp transection of the broad ligaments (Broome et al. 1992, Santschi et al. 1995). Use of an automatic stapling instrument (LDS stapler) has also been described (Rötting et al. 2003).

Caudal transection of the genital tract and subsequent secure closure of the stump can be accomplished by several techniques. Various types of instruments are employed to occlude the genital tract temporarily before transection, and include the use of Glassmann gastroenterotomy clamps (Santschi et al. 1995), Doyen forceps (Hooper et al. 1992, Broome et al. 1992, Santschi et al. 1995), Best right angle colon clamps (Rötting et al. 2003), or the TA Premium 90 with a previously fired cartridge (Rötting et al. 2003). Closure of the caudal lumen has been described using a Parker-Kerr pattern (Santschi et al. 1995) or several inverting layers (Santschi et al. 1995, Rötting et al. 2003). In one mare with leiomysarcoma and chronic endometritis double application of a TA Premium 90 was used to occlude the uterine body (Santschi et al. 1995).

Postoperative complications associated with conventional OHE technique are frequently described. In a case report of 6 horses undergoing OHE for the treatment of pyometra, removal of a macerated fetus or leiomyosarcoma, 5 mares had postoperative complications. Abdominal pain was the most frequent problem (4 mares), requiring treatment with flunixin meglumine and butorphanol tartrate. Other complications included severe upper airway obstruction, severe abdominal hemorrhage, uterine stump infection 
or abscessation, jugular thrombosis, peritonitis, ileus, diarrhea, incisional infection and death (Santschi et al. 1995). In a report of 20 normal mares undergoing OHE by use of a chain ecraseur, postoperative vaginal bleeding (2 mares) and mesometrial remnant hematoma (1 mare) were described. No information was given about any other clinical parameters (Hooper et al. 1992). A recent publication describes 7 mares requiring OHE for chronic pyometra (4 mares), chronic uterine torsion (2 mares) and chronic intramural hematoma (1 mare). Postoperative complications included mild abdominal pain, decreased borborygmi with decreased fecal output, impaction of the small colon and rectum, decreased appetite, and mild to moderate incisional infection.

\subsection{Laparoscopic techniques}

\subsubsection{General aspects of laparoscopic techniques}

Laparoscopic techniques for a variety of procedures in horses have been described in recent years. The reported advantages include increased intraoperative visualization, the requirement for smaller incisions, less extensive manipulation of the abdominal viscera, reduced postoperative pain and reduced periods of convalescence compared with corresponding procedures performed using conventional methods (Palmer 1993, Ragle and Schneider 1995, Ragle et al. 1996b, Gottschalk and van den Berg 1997, Walmsley 1999, Hanson and Galuppo 1999). Disadvantageous are the capital costs associated with the equipment and consumables, the relative technical difficulty of certain procedures, the inaccessibility of some organs within the equine abdomen and technique specific complication, e.g. inadvertent organ penetration and electrosurgical heat damage (Palmer 1993, Walmsley 1999, Desmaizières et al. 2003).

\subsubsection{Hemostasis during laparoscopic ovariectomy in the mare}

Ovariectomy techniques have been described for mares in the standing (Palmer 1993, Bouré et al. 1997, Gottschalk and van den Berg 1997, Hanson and Galuppo 1999, Rodgerson et al. 2001, Hand et al. 2002, Düsterdieck et al. 2003) and dorsally recumbent position (Ragle and Schneider 1995, Ragle et al. 1996b). 
A variety of methods have been successfully employed to achieve hemostastis of the ovarian pedicle. Palmer (1993) was the first to describe laparoscopic ovariectomy in the mare. He utilized a ND:YAG laser for tissue dissection and minor hemostasis. Occlusion of the ovarian artery was achieved either with laparoscopic staplers or clips. Intracorporeal ligation, i.e. a modified Roeder knot using 3 polycglactin 910 and a custom made push rod system, followed by sharp transection was employed by other authors (Ragle and Schneider 1995, Ragle et al. 1996b, Hanson and Galuppo 1999). Minimal dissection was carried out before ligature application. Incomplete hemostasis on 3 out of 43 ovarian pedicles (Hanson and Galuppo 1999) and on 1 out of 30 ovarian pedicles (Ragle and Schneider 1995) were encountered and required application of an additional ligature. Failure of a 2 polycglactin 910 ligature was reported by Rodgerson and Hanson (2000). Alternatively, Bouré et al. (1997) described the application of 2 strands of a commercial polydioxanone Endoloop ligatures to achieve hemostastis (0 PDS Endoloop, Ethicon Inc. Québec. Canada). Dissection of the blood supply before transection was not performed, and complete hemostasis was reported on all 13 ovarian pedicles.

A unique ovariectomy technique was reported by Gottschalk and van den Berg (1997). The ovary was laparoscopically identified, desensitized, and subsequently exteriorized through a 5-8 cm long flank incision. A Sand emasculator was used to transect the mesovarium and the stump allowed to return into the abdominal cavity. Although the ovarian pedicle was reportedly under tension during transection, no hemorrhage was noted. Rodgerson et al. (2001) described a combined use of monopolar or bipolar electrosurgical instrumentation and sharp transection of the ovarian pedicle in 23 mares. Intraoperative hemorrhage occurred in some mares, but was easily controlled by reapplication of the electrosurgical instrumentation. The Harmonic Scalpel (Ethicon Endo-Surgery Inc., Cincinnati, $\mathrm{OH}$ ) was recently evaluated for its use during laparoscopic ovariectomy in the mare (Düsterdieck et al. 2003). Complete hemostasis was achieved in all 8 mares. One of the newest advancements is a vessel-sealing device (LigaSure Atlas Laparoscopic Sealer/Divider Instrument, Valleylab, Boulder, CO). The device uses high current and low voltage, along with pressure to reorganize the 
collagen into a translucent seal. It has been evaluated during laparoscopic ovariectomy in 13 mares, and complete hemostasis was always achieved (Hand et al. 2002).

\subsubsection{Technical aspects of the Harmonic Scalpel}

The Harmonic Scalpel is an ultrasonically activated blade that is able to cut and coagulate tissue at the same time. A piezoelectric crystal, activated by electric energy generates mechanical vibration of the instrument tip. The resulting heat combined with the mechanical energy causes the protein to denature, forming a coagulum (Mueller and Fritzsch 1994, McCarus 1996).

The generator has 5 power settings. Lower power settings provide better hemostasis but slower cutting speed, whereas higher power settings allow faster cutting but less hemostasis. The 3 different blade surfaces (sharp, blunt, flat) also offer different coagulation and cutting speed. The Harmonic Scalpel blade needs to be regularly cleaned throughout the procedure to ensure optimal coagulation and transection, and to prevent system shut-down (Düsterdieck et al. 2003).

3.2.3. Laparoscopic ovariohysterectomy (L-OHE) and laparoscopic hysterectomy (L-HE) in other species

Hysterectomy in women is performed using several different techniques, including abdominal approach, vaginal approach, total laparoscopic, laparoscopic-assisted vaginal, or a hand-assisted laparoscopic approach (discussed later). Laparoscopic hysterectomy (L-HE), i.e. either total laparoscopic or laparoscopic-assisted vaginal has been shown to cause less discomfort, shorter hospital stay, and quicker and better recovery compared to abdominal hysterectomy (Raju and Auld 1994, Eltabbakh et al. 2001, Schütz et al. 2002, Ayoubi et al. 2003, Ou et al. 2004). Disadvantageous are the increased surgical time and the higher surgical cost, however the total expenses are lower due to reduced hospital stay. Despite the clear advantages shown for the patient, acceptance rate amongst human physicians is low. Purported reasons for this are the 
high initial cost of the equipment and the technical difficulty associated with the procedure (Ou et al. 2004).

There are only a few reports documenting laparoscopic ovariohysterectomy (LOHE) and L-HE in animals. Minami et al. (1997) described for the first time laparoscopic treatment of pyometra in two dogs. Hemostasis of the ovarian pedicle and mesometrium was achieved using the Harmonic Scalpel. The genital tract was transected after exteriorization through the most caudal laparoscopic portal.

Austin at al. (2003) described a L-OHE technique in healthy bitches. A Harmonic Scalpel was used the achieve hemostasis and transection of the ovarian vascular pedicle, suspensory ligament, the broad ligament of the uterus, and across the caudal aspect of the uterus. The tissue was removed through one of laparoscopic portals. Postoperative swelling of some of the surgical incisions, omental herniation and incisional seroma formation in 1 dog were described.

A direct comparison of the L-OHE to conventional OHE via ventral midline celiotomy was undertaken by Davidson et al. (2004). Dogs undergoing the laparoscopic procedure were found subjectively and objectively to have lower pain and incisional scores postoperatively. The mean surgical time, however, was approximately twice as long for the L-OHE and more postoperative complications were encountered with the LOHE.

A technique for L-OHE in llamas and alpacas in dorsal recumbency has been described (Carpenter et al. 2000). To achieve hemostasis of the ovarian pedicles, laparoscopic clips were suggested, with subsequent sharp transection of the mesometrium. Separate occlusion of uterine arteries was not reported. The uterine body was occluded using intracorporeal ligation followed by sharp transection. The genital tract was exteriorized through on of the enlarged instrument portals.

A very similar approach for L-OHE and L-HE has been described in lions (Aguilar et al. 1997, Kolata 2002). A combination of different instruments (i.e. laparoscopic clips, 
laparoscopic stapler, suture loops, electrocautery, Harmonic Scalpel) was employed to achieve hemostasis of the ovarian pedicle and transection of the uterine body. None of the animals had postoperative complications.

\subsubsection{Hand-assisted laparoscopic surgery in human medicine}

Beginning in the early 1990s, direct manual manipulation during laparoscopy was performed through tight abdominal incisions (Boland et al. 1993). These so called minilaparotomies were used initially for nephrectomies. Soon, special devices were developed, facilitating the laparoscopic hand-assistance. Over the last 10 years, HALS technique has been employed for a variety of procedures. By far the most common indication is nephrectomy (Kercher et al. 2003, Maartense et al. 2004, Gaston et al. 2004, Brown et al. 2004). Other indications include liver resection (Fong et al. 2000, Shimizu et al. 2003, Hayakawa et al. 2004), pancreas surgery (Doi et al. 2003), splenectomy (Takahashi et al. 2004, Bermas et al. 2004), esophagectomy (Romanelli et al. 2001), gastric bypass surgery and gastrectomy (Romanelli et al. 2001, Sundbom and Gustavsson 2004), colorectal surgery (Loungnarath and Fleshman 2003, Nakajima et al. 2004, Kang et al. 2004), aortoiliac surgery (Wijtenburg et al. 2003), and hysterectomy (Pelosi and Pelosi 1999).

Validity of the HALS technique is still under discussion within the human medical profession (Wolf 2001, Gill 2001). When evaluating advantages and disadvantages of the HALS technique, it is important to differentiate comparison to either conventional laparoscopic technique or conventional approaches via laparotomy. Currently, HALS in human medicine is used most commonly as an alternative to standard laparoscopic techniques (Meijer et al. 2000, Wolf 2001). Table 1 summarizes some of the reported features of HALS vs. standard laparoscopy.

The key advantageous element is the option to use the "most proficient and versatile operative instrument available - the human hand" during laparoscopic procedures (Wolf 2001). The capability for tactile examination eliminates one of the major disadvantages reported for laparoscopic procedures (Wolf 2001, Freemann and 
Gallagher 2002, Romanelli et al. 2001). Technically complex laparoscopic procedures have been facilitated by the coordinate manual manipulation and retraction of tissues and manipulations of transabdominally placed instruments (Freemann and Gallagher 2002, Fong et al. 2000). Reducing the degree of difficulty resulted in less surgical time compared with routine laparoscopic methods and the requirement for less technical expertise (Troxel and Das 2001, Wolf 2001, Freemann and Gallagher 2002, Kercher et al. 2003). Reducing the degree of difficulty of certain operative procedures also results in shortening of the surgeon's learning curve (Wolf 2001, Gaston et al. 2004).

Tab. 2-1. Advantages and disadvantages of HALS technique vs. standard laparoscopy (Pelosi and Pelosi 1999, Fong et al. 2000, Wolf 2001, Gill 2001, Romanelli et al. 2001, Hanna et al. 2001, Kercher et al. 2003, Maartense et al. 2003)

\begin{tabular}{|c|c|}
\hline $\begin{array}{l}\text { Advantages } \\
\text { of HALS vs. standard laparoscopy }\end{array}$ & $\begin{array}{l}\text { Disadvantages } \\
\text { of HALS vs. standard laparoscopy }\end{array}$ \\
\hline - direct palpation of the organ & - time for device placement \\
\hline - blunt digital dissection of tissue & $\begin{array}{l}\text { - loss of intra- and extra-abdominal } \\
\text { work space }\end{array}$ \\
\hline - instant hemostasis & $-\mathrm{CO}_{2}$ leak \\
\hline $\begin{array}{l}\text { - less blood loss, but this is challenged } \\
\text { by others }\end{array}$ & - device malfunction \\
\hline - $\quad$ easier with shortened learning curve & - $\quad$ hand fatigue \\
\hline - faster, but this is challenged by others & $\begin{array}{ll}\text { - } & \text { added cost of the device } \\
\text { (not total surgery cost) }\end{array}$ \\
\hline $\begin{array}{l}\text { removal of large tissue specimen, i.e. } \\
\text { en bloc resection of tumors }\end{array}$ & $\begin{array}{l}\text { - increased wound morbidity and pain, } \\
\text { but this challenged by others }\end{array}$ \\
\hline $\begin{array}{l}\text { non-laparoscopic instruments can be } \\
\text { used intra-abdominally }\end{array}$ & $\begin{array}{l}\text { increased convalescence time, } \\
\text { but this is challenged by others }\end{array}$ \\
\hline $\begin{array}{l}\text { - may prevent conversion into open } \\
\text { laparotomy }\end{array}$ & - reduced cosmesis \\
\hline $\begin{array}{l}\text { wound protection, i.e. during tumor } \\
\text { removal }\end{array}$ & \\
\hline $\begin{array}{ll}\text { - } & \text { reduction in number of additional } \\
\text { laparoscopic portals }\end{array}$ & \\
\hline
\end{tabular}

In selected cases, standard non-laparoscopic instruments can be introduced through the access port. Described tools include a standard surgical handtowel for improved manual retraction of small intestine (Nakajima et al. 2004), bulldog clamps, 
sponges for hemostasis, and an ultrasound probe (Fong et al. 2000). Additionally the retrieval of large tissue specimens (i.e. kidney, tumor, uterus) can be readily performed through the hand access port (Fong et al. 2000, Wolf 2001, Freemann and Gallagher 2002, Romanelli et al. 2001, Troxel and Das 2001)

Disadvantages of HALS compared with standard laparoscopy in humans includes the potential reduction of internal and external surgical work space in small patients, the time required for device placement, difficulties maintaining abdominal insufflation, reduced cosmesis, increased morbidity compared with standard laparoscopic incisions and the expense of the device (Wolf 2001, Romanelli et al. 2001, Troxel and Das 2001, Hanna et al. 2001, Gill 2001).

Comparison between surgeries via open laparotomy and HALS are sparse. The major advantage of HALS vs. conventional open laparotomy is the reduced incisional length with subsequent decreased heat loss during surgery, less blood loss, and less postoperative pain scores (Fong et al. 2000, Kang et al. 2004).

In summary, hand-assisted laparoscopic surgery combines the convenience and safety of open surgical techniques with the advantages of minimally invasive surgery (Meijer et al. 2000).

Currently available HALS devices marketed for use in human surgery include the PneumoSleeve (Dexterity Surgical, San Antonio, TX), HandPort (Smith\&Nephew Inc., Andover, MA), Lapdisc (Ethicon Endo-Surgery, Cincinnati, OH), Intromit, GelPort (Applied Medical, Rancho Santa Margerita, CA) and the Omniport (Advanced Surgical Concepts, Dublin, Ireland). All of theses devices have their strengths and weaknesses and several human articles address their individual properties (Maijer et al. 2000, McGinnis et al. 2001).

The Omniport, which is used in the present study, is a hand and laparoscopic instrument access port for laparoscopic assisted surgery (Figure 1). The polyurethane cuff forms a one-chamber pneumohelix with 2 integrated rings. An insufflation valve with 
a stopcock is located near the outer ring. The device is inflated with a rubber bulb inflation pump. The device is available in 2 sizes (50 or $80 \mathrm{~mm}$ distance between the 2 rings) to accommodate patients with a range of abdominal wall thickness. For human patients the $50 \mathrm{~mm}$ version is recommended for body walls less than $40 \mathrm{~mm}$ thick and the $80 \mathrm{~mm}$ ring distance for body walls between $40-70 \mathrm{~mm}$ (Anonymous 2001).

\subsubsection{Hand-assisted laparoscopic surgery in veterinary medicine}

Ragle et al. (1996b) described the placement of a hand into the abdomen under laparoscopic visualization to retrieve a normal ovary and a large granulosa cell tumor. Recently, techniques were described for hand-assisted laparoscopic ovariectomy (Rodgerson et al. 2002), partial ovariohysterectomy (Janicek et al. 2004) and left sided nephrectomy (Keoughan et al. 2003) in standing horses. In those reports a hand port device was not used for the hand-assisted techniques. Abdominal insufflation was not maintained, however this did not prevent completion of the procedures (Rodgerson et al. 2002, Keoughan et al. 2003).

3.3. Anatomical aspects related to the female urogenital tract in the horse

\subsubsection{Female equine urogenital tract}

The mare has a uterus bicornis. The uterine body and the uterine horns are located in the caudal abdominal cavity and partly within the pelvic cavity. The cervix uteri is situated within the pelvic cavity. The body and horns are pressed against the dorsal abdominal wall and the rectum or may lay amongst large and small intestine. Ventrally, the uterine body is bordered by the urinary bladder. Anatomical positioning varies with stage of pregnancy as well as filling state and movement of the intestine and urinary bladder.

The uterine body and uterine horns are similar in length and measure about 18 to $25 \mathrm{~cm}$ each in the non-pregnant state. The uterine cervix is approximately 5 to $7 \mathrm{~cm}$ long. The wall of the uterus comprises the endometrium, a double layered myometrium 
and the outer perimetrium (Sisson 1975, Kainer 1993, Ley 1998, Übermuth et al. 1998). The oviduct courses from the blunt tip of the uterine horn to the ovary. The oviduct is suspended by the mesosalpinx, thus forming the lateral wall of the ovarian bursa. The medial wall of the ovarian bursa is formed by the proper ligament of the ovary (Dyce at al. 2002). The approximate position of the ovaries is ventral to the fourth or fifth lumbar vertebrae, but their exact location changes. The left ovary is positioned further caudal compared to the right ovary. The ovaries of the mare are kidney-shaped and measure about 7 to $8 \mathrm{~cm}$ along their long axis and 4 to $6 \mathrm{~cm}$ along the short axis. Ovarian size varies with the stage of the estrous cycle.

The broad ligaments connect the genital tract on each side to the dorso-lateral abdominal and pelvic walls, extending approximately from the third or fourth lumbar vertebrae to the fourth sacral vertebrae. They attach to the dorsal border of the uterine horns and follow to the lateral aspect of the body. Each ligament consists of two layers of peritoneum, enclosing a layer of smooth muscle, various amounts of fat and connective tissue, lymphatics, nerves and blood vessels. The ureters are found along the dorsal, parietal margins of the mesometrium. The round ligament of the uterus is located at the lateral aspect of the mesometrium. The ligament represents the homologue of the gubernaculum testis. It terminates in a blunt appendix (Ley 1998, Kainer 1993). The most cranial aspect of the broad ligaments form the mesovaria. Caudally, the broad ligament becomes continuous with the lateral ligaments of the bladder. The peritoneum reflects from the bladder onto the vagina, thus forming the vesicogenital pouch (Sisson 1975, Kainer 1993).

\subsubsection{Blood supply to the urogenital tract}

Uterine blood supply in horses is derived from 3 prominently anastomosing arteries on each side (Ginther et al. 1972). The cranial aspect is supplied by the uterine branch of the ovarian artery (cranial uterine artery). The ovarian artery is a direct branch of the abdominal aorta. The main blood supply to the uterus is through the uterine artery (middle uterine artery). This vessel originates from the external iliac artery. Caudally the uterus is supplied by the uterine branch of the vaginal artery (caudal uterine artery). The 
vessel passes along the lateral side of the cervix and uterine body and anastomoses with the cranial located arteries. The vaginal artery originates from the internal pudental artery. The blood supply to the ovary is through the tortuous ovarian branch of the ovarian artery.

An objective size determination of these vessels has not been reported. Subjective evaluation during surgery (Rodgerson et al. 2001) and measurements in a previously cited pilot study (Düsterdieck et al. 2003) indicated the ovarian artery was less than 3 $\mathrm{mm}$ in diameter. 


\section{MATERIAL AND METHODS}

\subsection{Animals used during the study}

Animals used for this study were donated to the Veterinary Teaching Hospital for euthanasia due to the existence of problems that did not require urgent care and were unrelated to the reproductive tract.

\subsection{Presurgical preparation}

The experimental protocol used for this study was approved by the Virginia Tech Animal Care and Use Committee. A non-survival pilot study was performed on 2 mares to develop the HALS-OHE technique. Six adult mares, with anatomically normal urogenital tracts were used to evaluate the method and any associated complication. Preoperative evaluation of the horses included a physical examination, a gynecologic examination (i.e. transrectal palpation, transrectal ultrasound and vaginal examination) as well as complete blood count and chemistry profile. Survival surgeries involved 1 Quarter Horse and 5 Thoroughbred mares that weighed between 442 and $567 \mathrm{~kg}$ and were 11 to 24 years old. One of the mares was a maiden mare (\#1) and 2 mares $(\# 5,6)$ were in estrus at the time of surgery. Table 81 to $8-3$ summarizes the preoperative findings in these mares.

Food and bedding was removed 48 hours before surgery. Mineral oil (3.7 liters) was administered via nasogastric tube 48 and 24 hours prior to surgery. Procaine penicillin $\mathrm{G}(22.000 \mathrm{IU} / \mathrm{kg}, \mathrm{IM})$ and flunixin meglumin $(1.1 \mathrm{mg} / \mathrm{kg}$, IV) were administered before surgery and every 12 hours after surgery for 60 hours. Before induction of anesthesia, feces were manually evacuated from the rectum to reduce potential interference with the laparoscopic field.

Horses were administered xylazine hydrochloride (0.5 to $1.2 \mathrm{mg} / \mathrm{kg}, \mathrm{IV}$ ) and guaifenesin (64 to $86 \mathrm{mg} / \mathrm{kg}$, IV). General anesthesia was induced with ketamine hydrochloride $(2.2 \mathrm{mg} / \mathrm{kg}$, IV). Following endotracheal intubation, general anesthesia 
was maintained with halothane in oxygen in the first 3 mares and with sevoflurane in oxygen in the remaining 3 mares in a semiclosed circle. All mares received butorphanol tartrate $(0.02 \mathrm{mg} / \mathrm{kg}, \mathrm{IV})$ at the beginning of the surgery and again $1-2$ hours following induction. Ventilation was supported by positive pressure ventilation throughout the procedure. Patient monitoring during the surgery included measurement of direct arterial blood pressure, arterial blood gases, end-tidal $\mathrm{CO}_{2}$ concentration, and electrocardiography. Horses received xylazine hydrochloride $(50-100 \mathrm{mg}$, IV) when placed in the anesthesia recovery box.

\subsection{Surgical Procedure}

After induction of general anesthesia, each horse was positioned in dorsal recumbency on a $25 \mathrm{~cm}$ thick foam pad. The ventral abdomen was clipped using a no.40 blade. Surgical field extended from the xiphoid to the perineum and laterally to the folds of the flank. The surgical field was prepared using routine aseptic technique.

An $11 \mathrm{~cm}$ skin incision was made over the cranial aspect of the longitudinal intermammary groove. The incision continued through the subcutaneous tissue, along the medial suspensory laminae and the linea alba, bisecting the mammary gland. Hemorrhage from the subcutaneous tissue was controlled with monopolar electric cautery. Once the laparotomy was made, the hand access port was lubricated with $1 \%$ carboxymethylcellulose (Aqualon, Wilmington, DE), and both rings were compressed into an oval configuration (Fig 2). The device was obliquely inserted completely into the abdomen. The outer ring was grasped and gently exteriorized out of the abdomen through the incision, while the other ring remained intraabdominal, against the peritoneum. Care was taken to ensure that abdominal viscera were not positioned between the inner ring and the peritoneum.

The left ovary was approached first in each mare with the primary surgeon positioned on the left side of the horse. The $1^{\text {st }}$ assistant, positioned on the right side of the horse, inserted the right hand through the hand access port into the abdomen and the device inflated using the inflation pump to effect a seal between the arm and the 
incision (Fig 3). Approximately 100 to $200 \mathrm{ml}$ of carboxymethylcellulose was used to ease hand insertion. A $1.5 \mathrm{~cm}$ incision was made through the skin and linea alba over the umbilicus. Using the hand placed into the abdomen, the $1^{\text {st }}$ assistant elevated the ventral abdominal wall and provided counter pressure while an $11 \mathrm{~mm}$ laparoscopic sleeve with sharp pyramidal trocar was passed into the abdomen. The sharp trocar was removed and replaced by a laparoscope (Hopkins Telescope, $10 \mathrm{~mm} \times 57 \mathrm{~cm}, 30^{\circ}$ angle; Karl Storz Endoscopy, Goleta, CA). A $2^{\text {nd }}$ assistant, also positioned on the right side of the horse, controlled the laparoscope. The monitor was placed caudally.

Capnoperitoneum was established to 10 to $15 \mathrm{mmHg}$ and maintained using an automatic insufflator (Electronic Laparoflator 26012, Karl Storz Endoscopy, Goleta, CA). After capnoperitoneum was achieved, the surgical table was tilted about $13^{\circ}$ in a head down position and mares were rotated slightly to the right of dorsal recumbency to improve exposure to the left ovary.

An instrument portal was similarly made located on the ventral midline slightly cranial to the midpoint between the umbilicus and the cranial aspect of the hand access port laparotomy incision (Fig 4). A laparoscopic claw forceps was passed through this portal and used by the $1^{\text {st }}$ assistant to manipulate the ovary and mesometrium. The left ovary was placed manually under cranial traction and a $3^{\text {rd }}$ (left ovarian) portal was made approximately $5 \mathrm{~cm}$ cranio-lateral to the ventral projection of the ovary. A $1.5 \mathrm{~cm}$ incision through the skin and external rectus sheath was made, and a $12 \mathrm{~mm}$ laparoscopic sleeve with sharp pyramidal trocar (Endopath 512, Surgical Trocar $12 \mathrm{~mm}$ x $100 \mathrm{~mm}$; Ethicon, Endo-Surgery, Cincinnati, $\mathrm{OH}$ ) was passed through the abdominal wall.

The left ovary was immobilized manually and infiltrated with $15 \mathrm{ml}$ of $2 \%$ mepivacaine delivered through a laparoscopic injection cannula passed through a reduction sleeve placed in the left ovarian portal. A laparoscopic stapling instrument (Endo GIA II with $3.5 \mathrm{~mm} / 60 \mathrm{~mm}$ cartridge; United States Surgical Corp, Norwalk, CT) placed through the left ovarian portal was used to transect the mesovarium that had been manually placed perpendicularly into the instrument jaws (Fig 5). 
Subsequently, Laparoscopic Coagulating Shears (Harmonic Scalpel, $15 \mathrm{~mm}$ straight blade; $10 \mathrm{~mm} \times 34 \mathrm{~mm}$; Ethicon Endo-Surgery, Cincinnati, $\mathrm{OH}$ ) were inserted through the same portal and used for transection of the mesometrium (Fig 6). Most of the mesometrium was transected using the blunt blade at power setting 3 as described previously (Düsterdieck et al. 2003). When larger vessels were encountered (the middle uterine artery and its branches), the flat blade surface was applied proximal and distal on the vessel, followed by transection between. When hemostasis after use of the Harmonic Scalpel was incomplete, $9 \mathrm{~mm}$ titanium endoscopic clips (Endo Clip II ML; United States Surgical Corp, Norwalk, CT) were applied to provide hemostasis. On some occasions, large vessels were first skeletonized with the Harmonic Scalpel and endoscopic clips applied proximal and distal prior to transection (Fig 7). Mesometrial transection was continued to the level of the caudal uterine body.

The mare was then rotated to a slightly left oblique position and the positions of the surgical team reversed. A $4^{\text {th }}$ (right ovarian) portal was made cranio-lateral to the right ovary and the right mesovarium and mesometrium was transected as described above.

The hand access port was deflated and removed and the operating table was returned to a horizontal position. The uterus and ovaries were exteriorized through the caudal midline laparotomy. Remaining caudal uterine arterial branches along the body of the uterus were ligated with no. 2-0 polyglactin 910 and transected as needed. Two large Carmalt forceps were applied transversely across the uterine body at the most caudal accessible extent and the uterus was transected between them (Fig 8). The uterine stump was closed using no. 1 polydioxanone suture in a Parker-Kerr pattern (Fig 9 and 10). The linea alba was closed using no. 2 polyglactin 910 in a simple continuous pattern. The mammary gland and subcutaneous tissue were apposed using no. 2-0 polyglactin 910 in a simple continuous pattern. Skin incisions were closed using no. 2-0 nylon in a simple continuous pattern for the laparotomy incision and 2 or 3 simple interrupted sutures for the laparoscopic portal incisions. 
Operative and recovery times, hemorrhage and methods of hemostasis as well as complications during and after surgery were recorded. Operative time was defined as the time from the first skin incision to completion of skin closure. Recovery time was the time between disconnecting the horse from the anesthetic circuit until the horse was standing.

\subsection{Post surgical management}

Horses were stalled confined after surgery except for periods of exercise walking in hand twice daily beginning the day after surgery. Feed was gradually reintroduced, starting with minimal amounts offered hourly from the day of surgery. Physical examinations were performed hourly during the first 8 hours after surgery, every 6 hours during the next 24 hours ( $1^{\text {st }}$ postoperative day) and twice daily through day 7 , and once daily for the remainder of the study. Variables included general attitude, pulse and respiratory rate, body temperature, appetite, borborygmi, defecation, urination and subjective evaluation of incisional healing. The packed cell volume and the plasma total protein were determined daily for 3 days after surgery.

\subsection{Post mortem evaluation}

Fourteen days after surgery, the mares were euthanized and abdominal cavities examined. The remnants of the broad ligaments and reproductive tract were evaluated for evidence of inflammation, adhesion, hematoma formation, and character of healing.

Samples from the amputated genital tract transection line were obtained and fixed in $10 \%$ neutral buffered formalin. Tissue specimen were subsequently embedded in paraffin, sectioned at $5 \mu \mathrm{m}$, and stained with hematoxylin and eosin. Histologic evaluation was performed to determine the level of transection (uterus or cervix). 


\section{RESULTS}

5.1. Intraoperative findings

Insertion of the Omniport was quick and easy. The $50 \mathrm{~mm}$ ring distance device was used in 2 mares and the $80 \mathrm{~mm}$ ring distance device in 4 mares. The hand port facilitated maintenance of abdominal insufflation while the $1^{\text {st }}$ assistants hand and forearm was positioned in the abdominal cavity. Small volumes of gas escaped during arm insertion and removal through the portal. Manipulation of the genital tract and intestine located in the caudal abdomen was readily performed under laparoscopic observation. Lifting the ovary and the uterus and gently stretching the mesovarium and mesometrium, respectively, facilitated accurate placement of the stapling instrument and Harmonic Scalpel. During transection of the mesometrium, digital palpation also permitted the identification of larger vessels that required occlusion before division. Generally, there was good exposure and visibility of the ovaries, uterus and the mesometrium with occasional interference by large intestine. When this occurred, the viscera could be repelled with the intra-abdominal hand and the genital tract lifted for optimal instrument placement. Paresthesia and fatigue of the intra-abdominal hand occurred periodically and was most often associated with overinflation of the hand port and sustained digital traction during isolation and positioning of blood vessels for occlusion, respectively.

Ovarian artery hemostasis and mesovarial transection was complete in all mares. Hemostasis of large vessels within the mesometrium using the Harmonic Scalpel was inadequate in 3 mares (\# 1,4,5); hemorrhage was controlled by subsequent application of endoscopic clips. In some instances occlusion of large vessels was performed with endoscopic clips before transection with the Harmonic Scalpel. Generally, branches of the caudal uterine artery were occluded and transected using the Harmonic Scalpel during laparoscopy. In 3 mares (\# 3-5), right caudal uterine arterial branches were ligated and transected after the uterus was exteriorized (Table 8-5). Transection and closure of the uterine stump presented no difficulties, though the exteriorized uterus was 
under moderate tension. Surgical time ranged from 150 to 210 minutes and decreased as the experience of the surgical team with the procedure increased.

No substantial intraoperative anesthetic complications were observed. Mare 1 had bradycardia (heart rate $<20 \mathrm{bpm}$ ) and occasional $2^{\circ}$ atrioventricular block, and mare 2 had a few ventricular premature contractions. All mares had episodes of hypotension (mean arterial pressure $<70 \mathrm{~mm} \mathrm{Hg}$ ), which responded to treatment with dobutamine (1$5 \mu \mathrm{g} / \mathrm{kg} / \mathrm{min}$ ). Anesthetic recovery times ranged from 40 to 100 minutes in 5 horses. One mare (\# 3) was unable to rise and was subsequently euthanatized (Table 8-4).

\subsection{Postoperative findings}

Pulse and respiration rates, and body temperatures returned to or remained within normal limits during the first 24 hours after surgery in 4 mares (\# 1, 2, 5,6). Five hours after surgery, mare 2 had signs of abdominal discomfort (heart rate $68 \mathrm{bpm}$ recumbency) that resolved after administration of $100 \mathrm{mg}$ xylazine hydrochloride. Mare 1 had pyrexia $\left(102.4^{\circ} \mathrm{F}\right) 4$ hours after surgery that resolved after a scheduled administration of flunixin meglumine. Mare 6 developed intermittent pyrexia $\left(<102.0^{\circ} \mathrm{F}\right)$ from the $3^{\text {rd }}$ to 5 th postsurgical day that resolved after administration of $0.5-1.1 \mathrm{mg} / \mathrm{kg}$ flunixin meglumine once daily for 3 days. The 4 mares had good appetites and were fed ad libidum within 24 hours after surgery. Borborygmi were slightly decreased on the day of surgery, but returned to normal during the subsequent 24 hours. Defecation and urination was noted in all 4 mares within the first 24 hours after surgery (Table 8-7 to 812). Mare 4 did not return to normal after surgery but appeared depressed and had a decreased appetite throughout the entire postoperative evaluation period. Because of intermittent tachycardia, tachypnea, and pyrexia, the mare was administered flunixin meglumine and procaine penicillin from the $5^{\text {th }}$ postsurgical day onwards. Based on clinical and ultrasonographic evaluations, pleuropneumonia was suspected and confirmed on necropsy on the $12^{\text {th }}$ day.

All but 1 surgical wound had uncomplicated healing. Mare 6 developed purulent discharge from the celiotomy incision on the 13th day. In mares 5 and 6 transient 
hematoma formation was encountered at 1 ovarian laparoscopic portal site. Three mares (\# 2,4,6) developed mild-to-moderate ventral edema. Infrequently, small volumes of serosanguineus vaginal discharge was observed in 4 mares $(\# 1,2,5,6)$ and persisted for 5 days in 1 mare (Table 8-6).

Except for 2 mares, PCV and the plasma total protein concentration remained within physiologic ranges postoperatively. A decline in PCV was observed in mare 1 (from $39 \%$ to $26 \%$ ) and mare 4 (from $38 \%$ to $20 \%$ ) (Table $8-13$ ).

\subsection{Necropsy Findings}

Surgical incisions were healing normally in all but mare 6 . In this mare, subcutaneous suppuration of the caudal median celiotomy incision, adhesions between the descending colon, its mesocolon, and the abdominal incision, as well as, multiple small fibrous tags (10-20 mm length) on the serosa of the cecum and ascending colon were observed. Adhesion formation to the surgical site was not observed in any other mare. In mare 1, a $50 \mathrm{~mm} \times 50 \mathrm{~mm}$ area of peritoneum ventrolateral to remnant of the left broad ligament was covered by a thin layer of fibrous tissue. The mare euthanatized in the recovery sall had bilateral femoral fractures. Mare 4 on the $12^{\text {th }}$ day had severe locally extensive, acute to subacute pleuropneumonia and a moderate subacute generalized peritonitis. Bacterial cultures obtained from multiple organs yielded Pasteurella multocida, Klebsiella pneumonia, Brevundimonas sp. and a-hemolytic Streptococcus sp.

The transection line of the mesovarium, mesometrium, and uterine remnant were healing routinely in all 5 mares recovered from anesthesia. A smooth, $1 \mathrm{~mm}$ layer of tanpink colored fibrous tissue covered the staples along the ovarian pedicle and the suture line on the uterine remnant. Small (5-10 mm diameter), firm, brown nodules along the mesometrial transection line were observed in the vicinity of larger blood vessels. Caudal to the more highly vascular area, the mesometrial boundary appeared as a thin line without discoloration or thickening. Mare 5 had 2 organized hematomas approximately $60 \mathrm{~mm}$ diameter within 1 mesometrium and a small seroma in the 
contralateral mesometrium (Table 814). Histologic evaluation of the amputated genital tracts indicated that transection was completed within uterine tissue in all horses. 


\section{Discussion}

In the present study, a minimally invasive HALS technique for OHE in mares with normal urogenital tracts was developed and evaluated. Although the indications for HALS-OHE in mares may be limited, the technical advantages of HALS technique may be applicable to other equine abdominal procedures currently performed using either a conventional open approach or laparoscopic techniques.

The hand access port allowed manual access to the abdominal cavity under laparoscopic observation while capnoperitoneum was effectively maintained. The use of the intra-abdominal hand facilitated protection of viscera during laparoscopic portal placement, stabilization of ovaries during injection of anesthetic, and the ligation and division of the mesovarium and broad ligament. Additionally, viscera were manually retracted to improve observation, and prompt hemostasis was achieved by digital pressure when hemorrhage occurred. The advantage of instant hemostasis was reported by Maartense et al. (2003); during HALS living donor nephrectomy renal artery clip dislodgment could be addressed without conversion to laparotomy.

In humans a reported disadvantage of HALS compared with standard laparoscopy is the reduction of internal and external surgical work space in small patients (Hanna et al. 2001). In contrast with humans, the large size of the equine abdomen provided ample surgical workspace and no interference between the hand and laparoscopic instrument manipulation; but resulted in the disadvantage of requiring 3 scrubbed surgeons, similar to a previous report of conventional OHE in horses (Santschi at al. 1995). Recommendations in humans are, that the primary surgeon inserts his or her non-dominant hand into the abdomen whereas the external (dominant hand) holds the laparoscopic instruments (Romanelli et al. 2001, Hanna et al. 2001).

Other obstacles described for the use of HALS in human surgery includes the additional time required for device placement (Gill 2001). We observed that placement of the hand access port required little time and was technically simple. In our study, loss of 
capnoperitoneum was encountered only when the arm of the $1^{\text {st }}$ assistant was removed from the port.

Though intended for single use, it is possible that the cost of the Omniport device (\$350) may be recovered over several cases. The devices used in our study were gas sterilized (Ethylenoxyd, $37^{\circ} \mathrm{C}, 7 \mathrm{~h} 45 \mathrm{~min}$ ) and used for multiple horses without loss of function in our study. It was not determined how many times the hand access devices could be reused without loss of function.

Techniques have been recently described for hand-assisted laparoscopic ovariectomy, partial OHE and left-sided nephrectomy in standing horses (Rodgerson et al. 2002, Keoughan et al. 2003, Janicek et al. 2004). In these reports a hand port device was not used. Intraabdominal visibility was satisfactory without establishment and maintenance of capnoperitoneum. However, it is important to note that adequate laparoscopic observation depends to a greater extent upon maintenance of adequate abdominal insufflation for horses in dorsal recumbency compared with standing laparoscopic procedures.

Optimal use of the hand access port is influenced by several factors including port location, incisional length, and hand port size. In our study, the hand port celiotomy incision was positioned just cranial to the pubic brim to maximize genital tract exteriorization after transection of the mesovarium and mesometrium. Romanelli et al. (2001) emphasize the importance of port placement and recommends portal placement to allow for triangulation technique and forward access of the hand in order to optimize visualization and hand comfort. Additionally, the location should be chosen to allow for open conversion. Insufficient incisional length for placement of the hand portal device has been reported to result in obstruction of circulation in the surgeon's hand, resulting in paresthesia (Meijer et al. 2000, Hanna et al. 2001). Occasional paresthesia observed in this study was alleviated by reducing the cuff inflation pressure of the hand portal device. In our study, an incisional length of approximately $11 \mathrm{~cm}$ was adequate to comfortably accommodate the forearm of the $1^{\text {st }}$ assistant and was adequate for removal and resection of normal urogenital tracts. Clinical conditions such as pyometra may 
require the length of the incision to be increased to permit safe exteriorization. We believe the resulting incision would be considerably $<40 \mathrm{~cm}$ length reported for conventional OHE in horses (Santschi et al. 1995). Selection of the Omniport size (80 $\mathrm{mm}$ versus $50 \mathrm{~mm}$ ring distance) was made by estimation of body wall thickness once the caudal midline laparotomy was completed. For human patients the $50 \mathrm{~mm}$ version is recommended for body walls $<40 \mathrm{~mm}$ thick and the $80 \mathrm{~mm}$ ring distance for body walls between 40 and $70 \mathrm{~mm}$ (Anonymous 2001).

In our study the surgical table was inclined approximately $13^{\circ}$ from horizontal (the maximum possible). This is considerably less than the $30^{\circ}$ incline previously reported for ventral laparoscopic ovariectomy (Ragle and Schneider 1995); however, exposure of the ovaries and uterus during the surgery was judged to be adequate in our study. The need for urinary bladder catheterization as previously reported was not apparent (Ragle and Schneider 1995). In addition to inclination of the surgical table, tilting the mares slightly to the side opposite the side being operated displaced the abdominal viscera and was judged to be important for laparoscopic observation. Less incline should contribute to reduced intraabdominal pressure on the diaphragm, reduced respiratory impairment and a decreased anesthetic risk compared with steeper inclines. It was shown previously, that horses undergoing abdominal insufflation with $\mathrm{CO}_{2}$ whether or not in head-down body position are potentially at increased risk of perioperative complications due to hypercapnia, acidosis and an increased cardiac work (Galuppo et al. 1996, Donaldson et al. 1998). Severe intraoperative anesthetic complications were not observed in the present study.

A variety of methods have been reported for achieving hemostasis of the ovarian and uterine arteries during laparoscopic and non-laparoscopic ovariectomy and OHE in horses (Santschi et al. 1995, Hooper et al. 1992, Santschi and Slone 1995, Düsterdieck et al. 2003, Rodgerson et al. 2002, Ragle and Schneider 1995, Palmer 1993, Rodgerson et al. 2001, Bouré et al. 1997). In our study, hemostasis of the ovarian pedicle was consistently achieved by single application of a laparoscopic stapling instrument $(60 \mathrm{~mm}$ / $3.5 \mathrm{~mm}$ staples). Although reported previously that the use of the Harmonic Scalpel produced adequate hemostasis of the ovarian pedicle (Düsterdieck et al. 2003), the 
surgical time saved by using a laparoscopic stapler was thought to be advantageous in our study. Hemostasis of the vessels within the mesometrium was not always achieved using the Harmonic Scalpel. The Harmonic Scalpel has a reported $85 \%$ success rate of sealing arteries up to $3.5 \mathrm{~mm}$ in diameter, pressurized to $300 \mathrm{~mm} \mathrm{Hg}$, at a power setting of 3 (Spivak et al. 1998).

The size of the vasculature in the mesometrium has not been determined. The diameter of the middle uterine artery is considerably larger compared to the other uterine arteries (Ginther et al. 1972), and it is likely increased in multiparous mares and those with chronic uterine disease. It is possible that the larger vessels within the mesometrium exceeded the capacity of the Harmonic Scalpel to seal consistently. Because of branching of the middle uterine artery at approximately $5 \mathrm{~cm}$ from the uterus (Ginther et al. 1972), transection of the mesometrium closer to the uterus necessitates the division of more but smaller vessels. In our study, endoscopic vascular clips consistently provided complete hemostasis, though the larger vessels required skeletonization of the vessel with the Harmonic Scalpel before clip application for secure closure. Digital manipulation allowed positioning of the vessel for accurate clip application. A time-saving but more expensive alternative would be the second application of the laparoscopic stapling instrument to incorporate the middle uterine artery and its branches bilaterally. Alternatively, HALS facilitates intracorporeal knot tying and suturing (Hanna et al. 2001), and it is conceivable that this could have been employed during the present study. Extracorporeal ligation of the caudal uterine artery at the level of the caudal uterus and cervix was performed as recommended for conventional OHE (Walker and Vaughan 1980); however, consistent with a previous report, this vessel was not encountered in all mares (Santschi et al. 1995).

For clinical OHE in horses it has been recommended to remove as much uterine tissue as possible (Santschi et al. 1995). In our study, amputation of the genital tract was performed as caudally as possible. Histologic examination revealed that transection was completed within uterine tissue in all horses. Previous reports describe the transection within uterine, cervical, or vaginal tissue (Broome et al. 1992, Santschi et al. 1995, Rötting et al. 2003). In our study secure uterine stump closure was achieved using a 
Parker-Kerr pattern. The use of a stapling instrument, i.e. TA Premium 90 would likely facilitate a more caudal transection, but staple arm length $(4.8 \mathrm{~mm} \times 90 \mathrm{~mm}$ cartridge) is potentially insufficient for secure closure of cervical or diseased uterine tissue (Santschi et al. 1995, Rötting et al. 2003). It is possible that in clinical conditions like pyometra, the genital tract would be considerably enlarged and amputation caudal to the cervix could be achieved using the described technique.

Surgical time ranged from 150 to 210 minutes and was considered excessive. Surgical time decreased as experience of the surgical team with the procedure increased. Reported operative time for unilateral or bilateral standing ovariectomy ranges from 45 to $120 \mathrm{~min}$ (Palmer 1993, Ragle and Schneider 1995, Hanson and Galuppo 1999). Additional reduction in surgical time could be achieved by the use of alternative methods of hemostasis. Application of the laparoscopic stapling instruments for mesometrial transection or the use of a vessel-sealing device (LigaSure Atlas Laparoscopic Sealer/Divider Instrument, Valleylab, Boulder, CO) for vessel coagulation are possibilities. It is anticipated that reduction in surgical time would reduce the occurrence of the $1^{\text {st }}$ assistant hand fatigue and may contribute to a reduced rate and severity of surgical complications.

Anesthetic recovery times in our study ranged from 40 to 100 minutes, which is comparable with a previous report on horses undergoing prolonged surgery in dorsal recumbency (Carroll et al. 1998). The oldest mare (24 years) fractured both femurs during anesthetic recovery. Based on her clinical appearance during anesthetic recovery a postanesthetic myopathy or neuropathy may have occurred but was not confirmed. Halothane has been shown to cause arterial hypotension and promotion of postoperative muscle dysfunction (Grandy et al. 1987). In a case report of 5 horses with myopathy affecting the hind limb adductor muscles, all had undergone prolonged anesthesia in dorsal recumbency (Dodman et al. 1998). It was suspected, that the medial circumflex femoral artery may have become occluded partially when the hind limbs were passively flexed. A semi-extended hind leg position was recommended as a preventative measure. All mares in the present study had their hind legs passively flexed, and the mare that developed bilateral femoral fractures had one of the shortest surgery times 
(150 minutes). Reduced bone density alone or in combination with an overall age related weakness may have contributed to her fractures.

Ovariectomy and especially surgical removal of granulosa cell tumors have been previously associated with a high incidence of paresis, and localized and generalized myositis, compared with horses undergoing other elective procedures (Meagher et al. 1977, Nickels 1988). Decreased arterial blood pressure was suggested to be causative (Meagher et al. 1977). All mares in the present study had periods of hypotension, however, were successfully treated for that. Ragle and Schneider (1995) observed postoperative complication in 5 out of 15 mares after bilateral laparoscopic ovariectomy via a ventral approach, including myositis of the gluteal musculature (1), and signs of abdominal pain within 60 to 90 min after recovery (4).

Four of 5 recovered mares were considered to have recuperated satisfactorily based on early return to normal vital signs. The signs of discomfort in mare 2 were considered mild and responded immediately to xylazine hydrochloride. Comparable values for normal mares after conventionally performed OHE are not available in the literature, and the present study was not designed for direct comparison of the two techniques. Previous reports on conventionally performed OHE in mares describe pain, decreased fecal output and borborygmi, diarrhea, septic peritonitis, uterine stump infection or necrosis, incisional infection, vaginal bleeding, hematoma in the remnant of the broad ligament, hemorrhage and death as postoperative complication (Torbeck et al. 1980, Hooper et al. 1992, Santschi and Slone 1994, Santschi et al. 1995, Rötting et al. 2003,). Signs of pain have been reported as mild and transient or severe requiring repeated treatment with analgesics (Torbeck et al. 1980, Santschi et al. 1995, Rötting et al. 2003). Discomfort in horses after conventional OHE has been suggested to result from excessive traction on the ovarian pedicle and broad ligament during uterine exteriorization (Santschi et al. 1995). Others have suggested decreased gastrointestinal motility or pain localized to the uterine stump that interferes with defecation, as the cause of mild postoperative colic (Rötting et al. 2003). Capnoperitoneum itself is suspected to be responsible for postoperative abdominal discomfort: $\mathrm{CO}_{2}$ and $\mathrm{H}_{2} \mathrm{O}$ from then moist peritoneal surfaces forming carbonic acid, and causing chemical peritonitis 
(Hulka and Reich 1994). This was challenged by other investigators: in humans undergoing laparoscopy, abdominal $\mathrm{pH}$ at the time of closure was not related to the degree of postoperative pain (Perry and Tombrello 1993).

The vaginal discharge we observed was limited to small amounts of serosanguineus fluid and was considered normal, consistent with a report on OHE in bitches (Pearson 1973). Contrary, true vaginal hemorrhage evidenced by the passage of blood clots has been reported following partial hysterectomy and ovariohysterectomy in horses (Hooper et al. 1992, Santschi and Slone 1994).

The inciting cause for the pleuropneumonia and peritonitis observed in mare 4 was not identified. The affected mare was an aged brood mare (22 years) from the teaching herd of our university. Despite normal presurgical appearance, exacerbation of a pre-existing subclinical condition is possible, as is the development of pleuropneumonia subsequent to general anesthesia and surgery. Pleuropneumonia is a recognized postanesthetic complication in human and veterinary medicine (Pascoe 1990, Kotani et al. 1995). Conditions resulting in suppression of pulmonary defense mechanisms have been associated with the development of pleuropneumonia in horses. These include transportation over long distances, strenuous exercise, laryngeal or pharyngeal dysfunction, or surgery with anesthesia (Racklyeft et al. 2000). A $0.4 \%$ incidence of pleuropneumonia after major surgical procedures was described, and healthy, young race horses presented for elective orthopedic procedures comprised most of the affected animals in one report (Pascoe 1990). Injectable and inhalant anesthetics together with endotracheal intubation are known to impair normal pulmonary defense mechanisms including mucociliary clearance rate and alveolar macrophage activity (Willoughby et al. 1991, Kotani et al. 1995). Additionally, the potential for increased risk for development of bacteremia and endotoxemia after capnoperitoneum has been described in humans (Neudecker et al. 2002). Bacterial isolates from cases with pleuropneumonia are typically organisms constituting the normal bacterial flora of the upper airways. Pasteurella spp. and Klebsiella spp. found in our mare are typical for horses with this condition (Sweeney et al. 1991, Raphel and Beech 1982), whereas ahemolytic Streptococcus spp. have been infrequently described (Burrell et al. 1986). The 
description of a Brevundimonas spp. isolatation from a horse was not found in the literature.

In a recent report on HALS for removal of ovarian tumors in horses, incisional drainage or dehiscence occurred postoperatively in 6 of 10 mares (Rodgerson et al. 2002). Incisional emphysema and edema is frequently described after standing laparoscopic ovariectomy; infection or dehiscence are rare occurrences (Gottschalk and van den Berg 1997, Bouré et al. 1997, Hanson and Galuppo 1999, Rodgerson et al. 2001). Wound healing complication was observed in one of the 5 horses recovered from anesthesia in our study. It is possible that the hand access device functions as mechanical protection to the wound edges during surgery. It should also be reiterated that the mares used in this study had clinically normal urogenital tracts and may be less prone to development of incisional complications than mares with uterine disease. Additional mare 1 in our study had a short period of postoperative hemorrhage from the umbilical portal. Mares 5 and 6 developed incisional swelling at one of the lateral laparotomy portals. Hemorrhage during surgery at this location was observed at these portals, and an incisional hematoma was therefore suspected. All healed without complication. Hemorrhage at various locations on the abdomen during portal placement have been reported (Palmer 1993, Ragle et al. 1998, Hanson and Galuppo 1999). The most frequently injured vessel during a ventral approach is the caudal epigastric artery and vein (Ragle et al. 1996a).

The overall complication rate in our study was high considering that normal mares were used; a higher complication rate might be expected in mares with clinical indications for OHE. Preoperative management, including uterine lavage has been used effectively to reduce the volume of uterine contents, the size of the reproductive tract and to reduce inflammation and vascularity of the associated tissues Broome et al. 1992, Boussauw et al. 1998). 


\section{Conclusion}

A HALS technique for OHE in the dorsally recumbent mare was successfully developed. Manual access to the laparoscopic field facilitated completion of an otherwise minimally invasive procedure. We demonstrated that HALS-OHE is technically feasible, and in selected cases may provide an alternative to conventional OHE. Two of the 6 mares had serious complications leading to their death. Whether these complications were attributable directly to the HALS-OHE technique was not determined. We feel that modifications in the technique that reduce surgical time would be beneficial and that careful case selection and preparation is important for a successful outcome. Only mares with uteri amenable to exteriorization through a relatively small incision should be selected for this technique. We anticipate that the HALS technique we used could be readily modified for development of other minimally invasive procedures of the equine abdomen or to compliment established laparoscopic procedures. 


\section{BIBLIOGRAPHY}

Aguilar R, Mikota SK, Smith J, et al.: Endoscopic ovariohysterectomy in two lions (Panthera Leon). J Zoo and Wildlife 28: 290-297, 1997

Anonymus: Instruction for use of the OmniportTM. ASC, Co. Wicklow, Ireland, 2001

Asbury AC, Lyle SK: Infectious causes of infertility, in: McKinnon AO, Voss JL (eds):

Equine Reproduction. Philadelphia, Lea and Febiger, 1993, pp 381-391

Austin B, Lanz OI, Hamilton SM, et al.: Laparoscopic ovariohysterectomy in nine dogs. J Am Anim Hosp Ass 39: 391-396, 2003

Ayoubi JM, Fanchin R, Monroezies X, et al.: Respective consequences of abdominal, vaginal, and laparoscopic hysterectomy on women's sexuality. Europ J of Obstet \& Gynec and Reprod Biology 111: 179-182, 2003

Berezowski C: Diagnosis of a uterine leiomyoma using hysteroscopy and a partial ovariohysterectomy in a mare. Can Vet J 43: 968-970, 2002

Bermas H, Fenoglio ME, Haun W, et al.: Hand-assisted laparoscopic splenectomy: indication and technique. JSLS 8: 69-71, 2004

Blomberg MS: Surgical neutering and nonsurgical alternatives. JAVMA 208: 517-520, 1996

Boland JP, Kusminsky RE, Tiely EH: Laparoscopic mini-laparotomy with manipulation: the midline path. Min Invas Ther 2: 63-67, 1993

Bouré L, Marcoux M, Laverty S: Paralumbar fossa laparoscopic ovariectomy in horses with use of Endoloop Ligatures. Vet Surg 26: 478-483, 1997 
Boussauw B, Santschi EM, Wilderjans $\mathrm{H}$, et al: Uterine drainage under general anesthesia before ovariohysterectomy in two mares. Vet Rec 23: 582-583, 1998

Broome TA, Allen D, Baxter GM, et al.: Septic metritis secondary to torsion of a pedunculated uterine fibroleiomyoma in a filly. JAVMA 200: 1685-1688, 1992

Brown JA, Hubosky SG, Gomella LG, et al.: Hand assisted laparoscopic partial nephrectomy for peripheral and central lesions: a review of 30 consecutive cases. J Urol 171: 1443-1446, 2004

Burrell MH, Mackintosh ME, Taylor CED: Isolation of Streptococcus pneumoniae from the respiratory tract of horses. Equine Vet J 18: 183-186, 1986

Carpenter EM, Hendrickson DA, Anderson DE: Laparoscopic ovariectomy and ovariohysterectomy in llamas and alpacas. Vet Clin North Am Equin Prac 16: 363-375, 2000

Carroll GL, Hooper RN, Rains CB, et al.: Maintenance of anesthesia with sevoflurane and oxygen in mechanically-ventilated horses subjected to exploratory laparotomy treated with intra- and post operative anaesthetic adjuncts. Equine Vet J 30: 402-407, 1998

Davidson EB, Moll HD, Payton ME: Comparison of laparoscopic ovariohysterectomy and ovariohysterectomy in dogs. Vet Surg 33: 62-69, 2004

Desmaizières L-M, Martinot S, Lepage OM, et al.: Complication associated with cannula insertion techniques used for laparoscopy in standing horses. Vet Surg 32: 501-506, 2003

Dodman NH, Williams R, Court MH, et al.: Postanesthetic hind limb adductor myopathy in five horses. JAVMA 193: 83-86, 1988 
Doi $R$, Ito D, Fujimoto K, et al.: Hand-assisted laparoscopic resection of serous cystadenoma of the pancreas. Surg Endosc 17: 2028-2031, 2003

Donaldson LL, Trostle SS, White NA: Cardiopulmonary changes associated with abdominal insufflation of carbon dioxide in mechanically ventilated, dorsally recumbent, halothane anesthetized horses. EVJ 30: 144-151, 1998

Doyle AJ, Freeman DE, Sauberli DS, et al.: Clinical signs and treatment of chronic uterine torsion in two mares. JAVMA 220: 349-353, 2002

Düsterdieck KF, Pleasant RS, Lanz OI, et al.: Evaluation of the Harmonic Scalpel for laparoscopic bilateral ovariectomy in standing horses. Vet Surg 32: 242-250, 2003

Dyce KM, Sack WO, Wensing CVG: The urogenital apparatus, in: Dyce KM, Sack WO, Wensing CVG (eds.) Textbook of Veterinary Anatomy. Philadelphia, WB Saunders, 2002, pp 166-209

Eltabbakh GH, Shamonki MI, Moody JM, et al.: Laparoscopy as the primary modality for the treatment of women with endometrial carcinoma. Cancer 2: 378-387, 2001

Fong $\mathrm{Y}$, Jarnagin W, Conlon KC, et al.: Hand-assisted laparoscopic liver resection Lessons from an initial experience. Arch Surg 135: 854-859, 2000

Freemann L, Gallagher LA: Disposable endoscopic instruments, in: Fischer AT (ed): Equine Diagnostic and Surgical Laparoscopy. Philadelphia, WB Saunders 2002; pp 5178

Galuppo LD, Snyder JR, Pascoe JR, et al.: Laparoscopic anatomy of the abdomen in dorsally recumbent horses. Am J Vet Res 57: 923-931, 1996

Gaston KE, Moore DT, Pruthi RS: Hand-assisted laparoscopic nephrectomy: prospective evaluation of the learning curve. J Urol 17: 63-67, 2004 
Gill IS: Hand-assisted laparoscopy: con. Urology 58: 313-317, 2001

Ginther OJ, Garcia MC, Squires EL, et al.: Anatomy of vasculature of uterus and ovaries in the mare. AJVR 33: 1561-1568, 1972

Gottschalk RD, van den Berg SS: Standing laparoscopically-aided ovariectomy in mares. J S Afr Vet Ass 68: 102-104, 1997

Grandy JL, Steffey EP, Hodgson DS, et al.: Arterial hypotension and the development of postanesthetic myopathy in halothane-anesthetized horses. Am J Vet Res 48: 192- 197, 1987

Hand R, Rakestraw P, Taylor T: Evaluation of a vessel-sealing device for use in laparoscopic ovariectomy in mares. Vet Surg 31: 240-244, 2002

Hanna GB, Elamass M, Cuschieri A: Ergonomics of hand-assisted laparoscopic surgery. Seminars in Laparoscopic Surgery 8: 92-95, 2001

Hanson CA, Galuppo LD: Bilateral ovariectomy in standing mares: 22 cases. Vet Surg 28: 106-112, 1999

Hayakawa K, Aoyagi T, Ohashi M, et al.: Comparison of gas-less laparoscopy-assisted surgery, hand-assisted laparoscopic surgery and pure laparoscopic surgery for radical nephrectomy. Int. J of Urol 11: 142-147, 2004

Hooper RN, Taylor TS, Behrens EA, et al.: Use of an ecraseur for ovariohysterectomy in mares. Vet Surg 21: 374-377, 1992

Hulka JF, Reich H: Gas and Pneumoperitoneum, in Hulka JF, Reich H (eds): Textbook of Laparoscopy. Philadelphia, WB Saunders, 1994, pp 47-50 
Janicek JC, Rodgerson DH, Boone BL: Use of a hand-assisted laparoscopic technique for removal of a uterine leiomyoma in a standing mare. JAVMA 225: 911-914, 2004

Kainer RA: Reproductive organs of the mare, in McKinnon AO, Voss JL (eds): Equine Reproduction. Philadelphia, Lea and Febiger, 1993, pp 8-19

Kang J-C, Chung M-H, Chao P-C, et al.: Hand-assisted laparoscopic colectomy vs open colectomy: a prospective randomized study. Surg Endosc 18: 577-581, 2004

Keoughan CG, Rodgerson DH, Brown MP: Hand-assisted laparoscopic left nephrectomy in standing horses. Vet Surg 32: 206-212, 2003

Kercher KW, Joels CS, Matthews BD, et al.: Hand-assisted surgery improves outcome for laparoscopic nephrectomy. Am Surg 69: 1061-1066, 2003

Klohnen A: History of laparoscopy in animals and humans, in Fischer AT (ed): Equine Diagnostic and surgical Laparoscopy. Philadelphia, WB Saunders, 2002, pp 3-6

Kolata RJ: Laparoscopic ovariohysterectomy and hysterectomy on African lions (Panthera Leo) using the Ultracision® Harmonic Scalpel®. J Zoo and Wildlife 33: 280282, 2002

Kotani N, Lin C-Y, Wang J-S, et al.: Loss of Alveolar macrophages during anesthesia and operation in humans. Anesth Analg 81: 1255-1262, 1995

Ley WB: Anatomy and physiology of the female reproductive system, in: Wolfe DF, Moll HD (eds): Large Animal Urogenital Surgery. Baltimore, Williams \& Williams, 1998, pp 8186

Loungnarath R, Fleshman JW: Hand-assisted laparoscopic colectomy technique. Semin laparosc Surg 10:219-230, 2003 
Maartense S, Bemelman WA, Gerritsen van der Hoop A, et al.: Hand-assisted laparoscopic surgery (HALS) - A report of 150 procedures. Surg Endosc. 18: 397-401, 2004

Maartense S, Heintjes RJ, Idu M, et al.: Renal artery clip dislodgement during handassisted laparoscopic living donor nephrectomy. Surg Endosc 17: 1850, 2003

McCarus SD: Physiologic mechanism of ultrasonically activated scalpel. J Am Assoc Gynecol Laparosc 3: 601-608, 1996

McGinnis DE, Gomella LG, Strup SE: Comparison and clinical evaluation of handassisted laparoscopy. Techniques in Urology 7: 57-61, 2001

Meagher DM, Wheat JD, Hughes JP, et al.: Granulosa cell tumors in mares - a review of 78 cases. Proc. AAEP 23th: 133-143, 1977

Meijer DW, Bannenberg JJG, Jakimowicz JJ: Hand-assisted laparoscopic surgery. Surg Endosc 14: 891-895, 2000

Minami S, Okamoto Y, Eguchi H, et al.: Successful laparoscopy assisted ovariohysterectomy in two dogs with pyometra. J Vet Med Sci. 59: 845-847, 1997

Mueller W, Fritsch G: Medicotechnical basics of surgery using invasive ultrasonic energy. End. Surg 2: 205-210, 1994

Nakajima K, Milsom JW, Margolin DA, et al.: Use of the surgical towel in colorectal handassisted laparoscopic surgery (HALS). Surg Endosc 18: 552-553, 2004

Neudecker J, Sauerland S, Neugebauer E, et al.: The european association for endoscopic surgery clinical practice guideline on the pneumoperitoneum for laparoscopic surgery. Surg Endosc 16: 1121-1143, 2002 
Nickels FA: Complication of castration and ovariectomy. Vet Clin North Am Equine Pract 4: 520-523, 1988

Ou C-S, Joki J, Wells K, et al.: Total laparoscopic hysterectomy using multifunction grasping, coagulation, and cutting forceps. J of Laparoendoscopy \& Advanced Surgical Technique 2: 67-71, 2004

Palmer SE: Standing laparoscopic laser technique for ovariectomy in five mares. JAVMA 203: 279-283, 1993

Pascoe JR: Postoperative Pleuropneumonia, in: White NA, Moore JN (eds): Current Practice of Equine Surgery. Philadelphia, JB Lippincott Company, 1990, pp 270-274

Pearson HJ: The complications of ovariohysterectomy in the bitch. J Sm Anim Pract 14: 257-266, 1973

Pelosi MA, Pelosi MA: Hand-assisted laparoscopy for complex hysterectomy. J Am Assoc Gynecol Laparosc 6: 183-188, 1999

Perry CP, Tombrello R: Effect of fluid instillation on postlaparoscopy pain. $\mathrm{J}$ of Reprod Med 38: 768-770, 1993

Racklyeft DJ, Raidal S, Love DN: Towards and understanding of equine pleuropneumonia: factors relevant for control. Aust Vet J 78: 334-338, 2000

Ragle CA, Schneider RK: Ventral abdominal approach for laparoscopic ovariectomy in horses. Vet Surg 24: 492-497, 1995

Ragle CA, Schneider RK, Southwood LL: Abdominal laparoscopy in horses. Comp Cont Edu 18: 1231-1241, 1996a 
Ragle CA, Southwood LL, Hooper SA, et al.: Laparoscopic ovariectomy in two horses with granulosa cell tumors. JAVMA 209: 1121-1124, 1996b

Ragle CA, Southwood LL, Schneider RK: Injury to abdominal wall vessels during laparoscopy in three horses. JAVMA 212: 87-89, 1998

Raju KS, Auld BJ: A randomised prospective study of laparoscopic vaginal hysterectomy versus abdominal hysterectomy each with bilateral salpingo-oophorectomy. B J of Obstetrics and Gynecology 12: 1068-1071, 1994

Raphel CF, Beech J: Pleuritis secondary to pneumonia or lung abscessation in 90 horses. JAVMA 181: 808-810, 1982

Rodgerson DH, Hanson RR: Ligature slippage during standing laparoscopic ovariectomy in a mare. Can Vet J 41: 395-397, 2000

Rodgerson DH, Belknap JK, Wilson DA: Laparoscopic ovariectomy using sequential electrocoagulation and sharp transection of the equine mesovarium. Vet Surg 30:572579,2001

Rodgerson DH, Brown MP, Watt BC, et al.: Hand-assisted laparoscopic technique for removal of ovarian tumors in standing mares. J Am Vet Med Assoc 220: 1503-1508, 2002

Romagnoli SE, Momant HW, Hilbert BJ, et al.: Multiple recurring uterocervical leiomyomas in two half-sibling appaloosa fillies. JAVMA 191: 1449-1450, 1987

Romanelli JR, Kelly JJ, Litwein DEM: Hand-assisted laparoscopic surgery in the United States: An overview. Seminars in Laparoscopic Surgery 8: 96-103, 2001

Rötting AK, Freeman DE, Doyle AJ, et al.: Total and partial ovariohysterectomy in seven mares. Equine Vet J 35: 29-33, 2003 
Santschi EM, Slone DE: Successful pregnancy after partial hysterectomy in two mares. JAVMA 205: 1180-1182, 1994

Santschi EM, Adams SB, Robertson JT, et al.: Ovariohysterectomy in six mares. Vet Surg 24: 165-171, 1995

Schütz K, Possover M, Merker A, et al.: Prospective randomized comparison of laparoscopic-assisted vaginal hysterectomy (LAVH) with abdominal hysterectomy $(\mathrm{AH})$ for the treatment of the uterus weighing >200g. Surg Endosc 16: 121-125, 2002

Shimizu T, Tajiri T, Akimaru K, et al.: Hand-assisted laparoscopic hepatectomy after partial splenic embolization. Surg Endosc 17: 1676-1679, 2003

Sisson S: Female genital organs, in: Sisson and Grossman's The anatomy of the domestic animals. Getty R (ed.), Vol. 1, 5th ed., Philadelphia, WB Saunders, 1975, pp 542-549

Slone DE: Ovariectomy, ovariohysterectomy and cesarean section in mares. Vet Clin NA Eq Prac 4: 451-459, 1988

Spivak H, Richardson WS, Hunter JG: The use of bipolar cautery, laparosonic coagulating shears, and vascular clips for hemostasis of small and medium-sized vessels. Surg Endosc 12: 183-185, 1998

Sundbom M, Gustavsson S: Randomized clinical trial of hand-assisted laparoscopic versus open Roux-en-Y gastric bypass for the treatment of morbid obesity. $\mathrm{Br} \mathrm{J}$ Surg 91: 418-423, 2004

Sweeney CR, Holcombe SJ, Barningham SC, et al.: Aerobic and anaerobic bacterial isolates from horses with pneumonia and pleuropneumonia and antimicrobial susceptibility patterns of the aerobes. JAVMA 198: 839-842, 1991 
Takahashi H, Yano H, Monden T, et al.: Hand-assisted laparoscopic splenectomy for solitary splenic metastasis from uterine corpus carcinoma. Surg Endosc 18: 345-349, 2004

Torbeck RL, Kittleson SL, Leathers CW: Botryoid rhabdomyosarcoma of the uterus of a filly. JAVMA 176: 914-916, 1980

Troxel S, Das S: Hand-assisted laparoscopic approach to multi-organ removal. J Endourol 15: 895-897, 2001

Übermuth K, Bartman CP, Wissdorf H: Weibliche Geschlechtsorgane, Milchdrüse und Harnröhre, in: Wissdorf H, Gerhards H, Huskamp B (eds): Praxisorientierte Anatomie des Pferdes. Hannover, M. \& H. Schaper Alfeld, 1998, pp 583-610

Vaughan JT: Equine urogenital system, in: Morrow DA (ed): Current Therapy in Theriogenology 2. Philadelphia, WB Saunders, 1986, pp 756-775

Walker DF, Vaughan JT: The equine female, in: Walker DF, Vaughan JT (eds): Bovine and equine urogenital surgery. Philadelphia, Lea \& Febiger, 1980, pp 185-260

Walmsley JP: Review of equine laparoscopy and an analysis of 158 laparoscopies in the horse. Equine Vet J 31: 345-464, 1999

Wijtenburg E, Remy P, D’hont Ch, et al.: Hand-assisted aortailiac surgery: preliminary report of 25 cases. Acta Chir Belg 103: 493-496, 2003

Willoughby RA, Ecker GL, McKee SL, et al.: Use of scintigraphy for the determination of mucociliary clearance rate in normal, sedated, diseased and exercised horses. Can J Vet Res 55: 315-320, 1991

Wolf JS: Hand-assisted laparoscopy: pro. Urology 58: 310-312, 2001 


\section{APPENDIX}

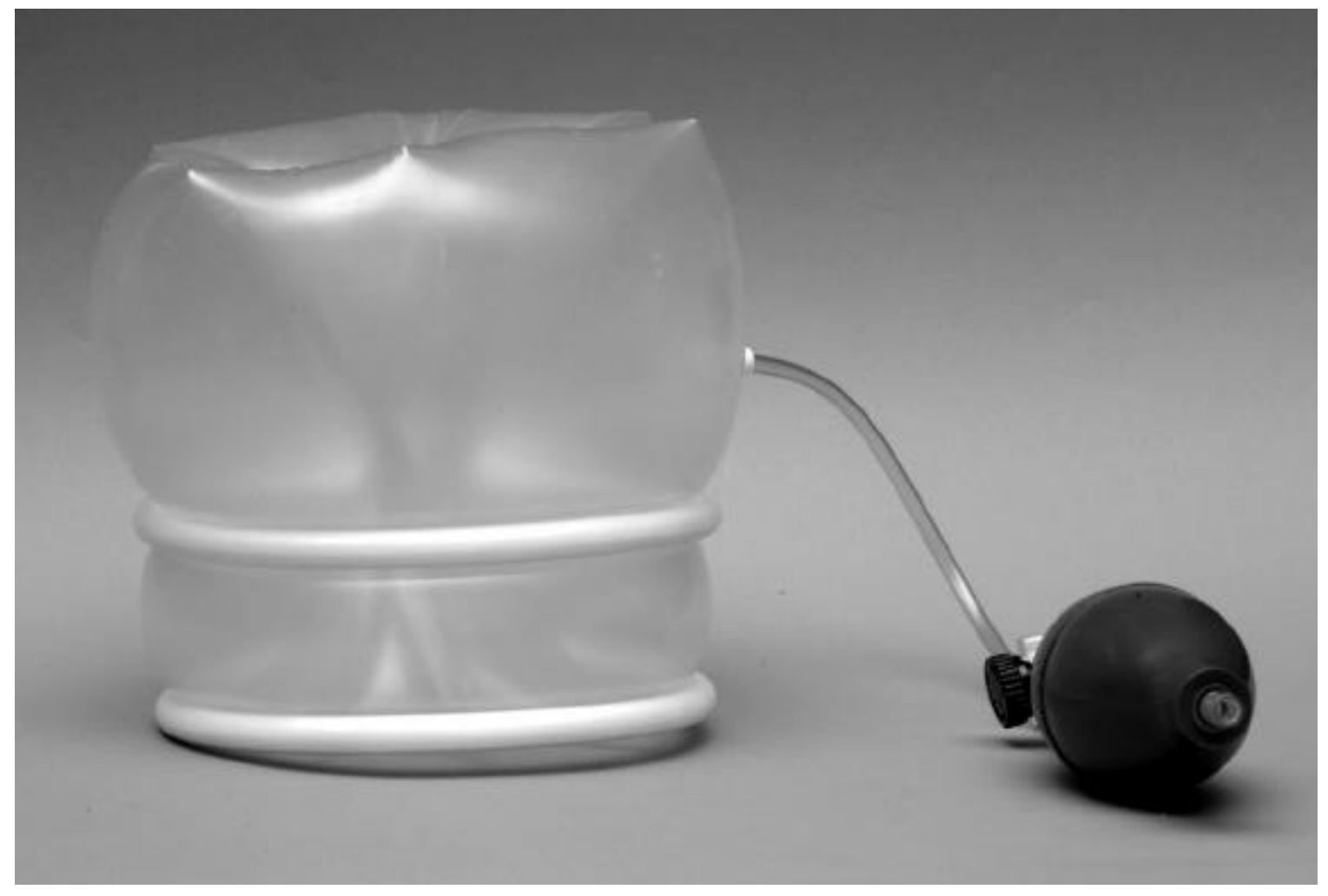

Figure 1. Omniport - a hand access port for hand-assisted laparoscopic surgery 


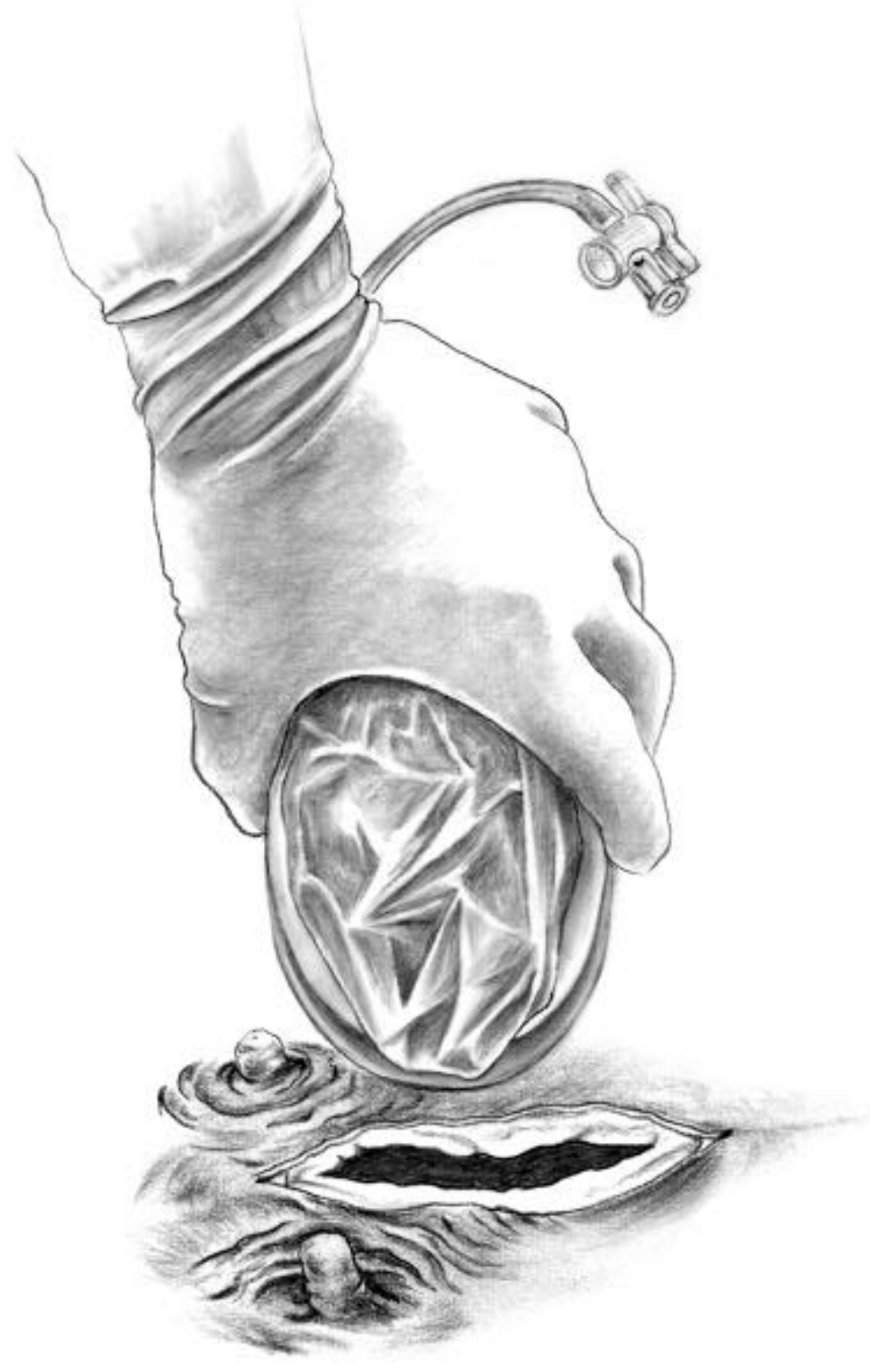

Figure 2. Insertion of the Omniport - both rings of the Omniport are compressed into an oval configuration to facilitate placement into the laparotomy 


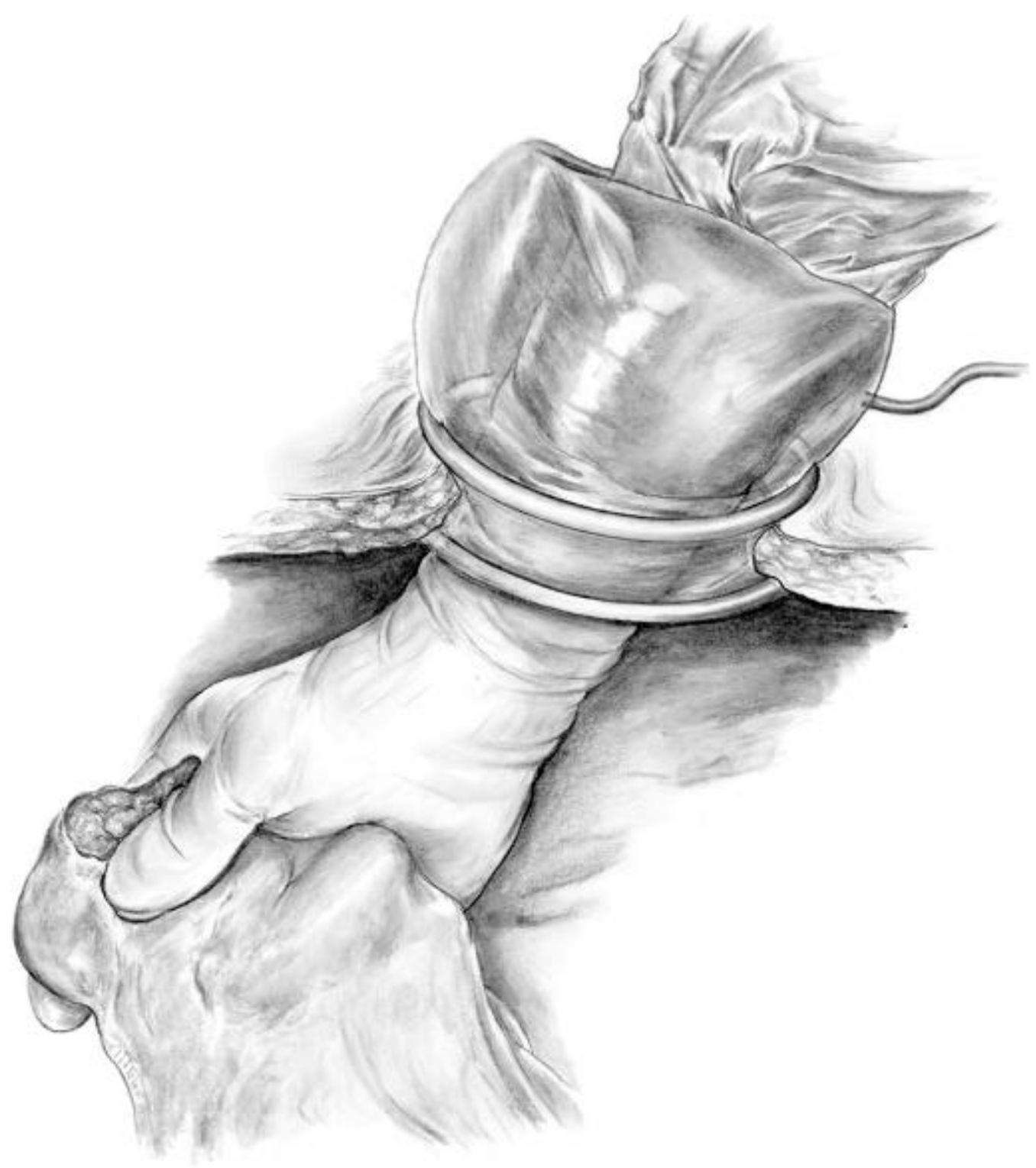

Figure 3. Hand placement through the Omniport - the assistant's hand in place through the hand access device into the abdomen 


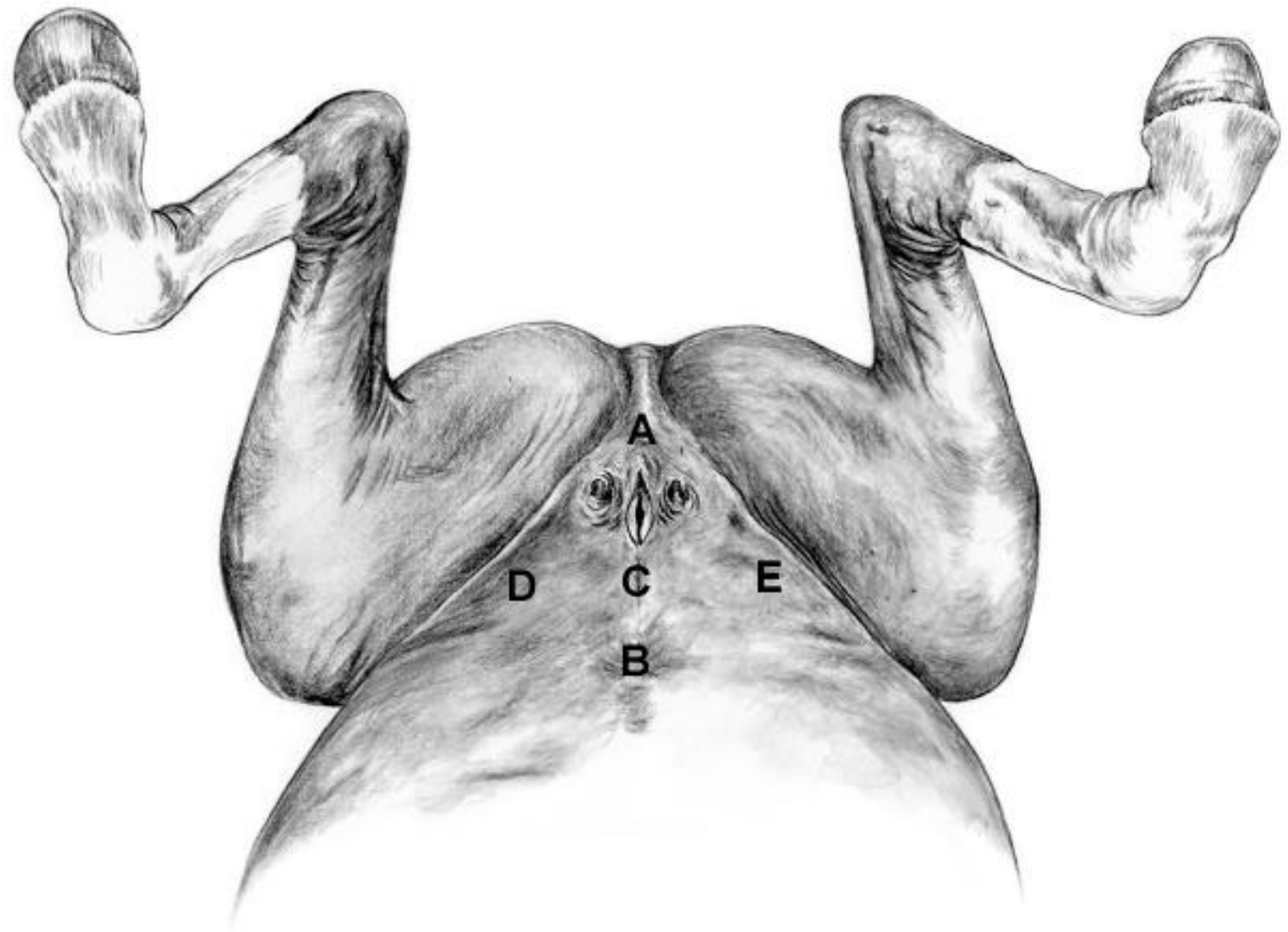

Figure 4. Location of the celiotomy and the laparoscopic portals caudal medial celiotomy for placement of the Omniport (A), the laparoscope portal (B), the instrument portal (C), the left ovarian portal (D), and the right ovarian portal (E) 


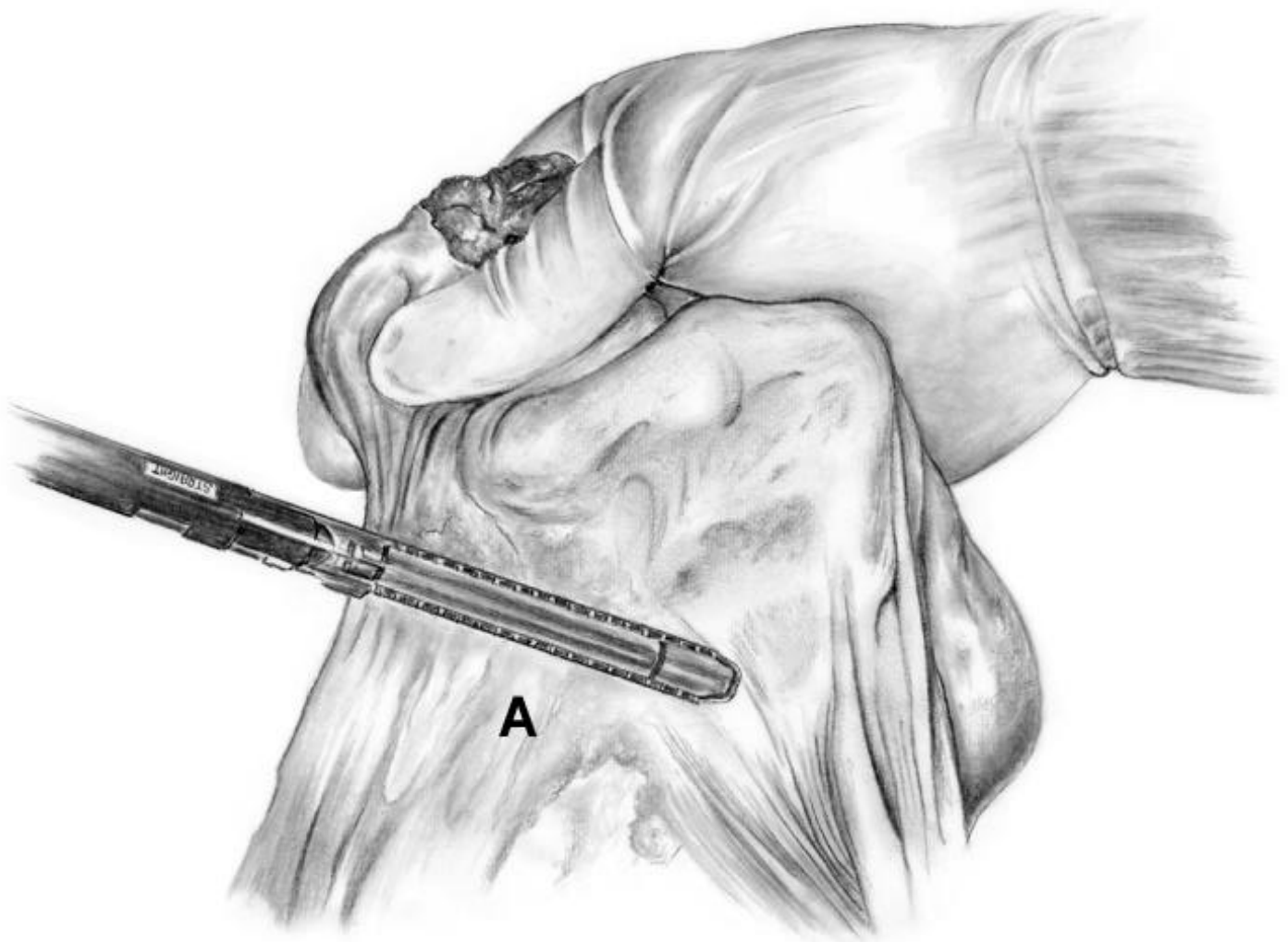

Figure 5. Application of the laparoscopic stapling instrument the assistant's right hand is holding the left ovary, and gently stretching the mesovarium (A) to permit perpendicular placement of the instrument jaws 


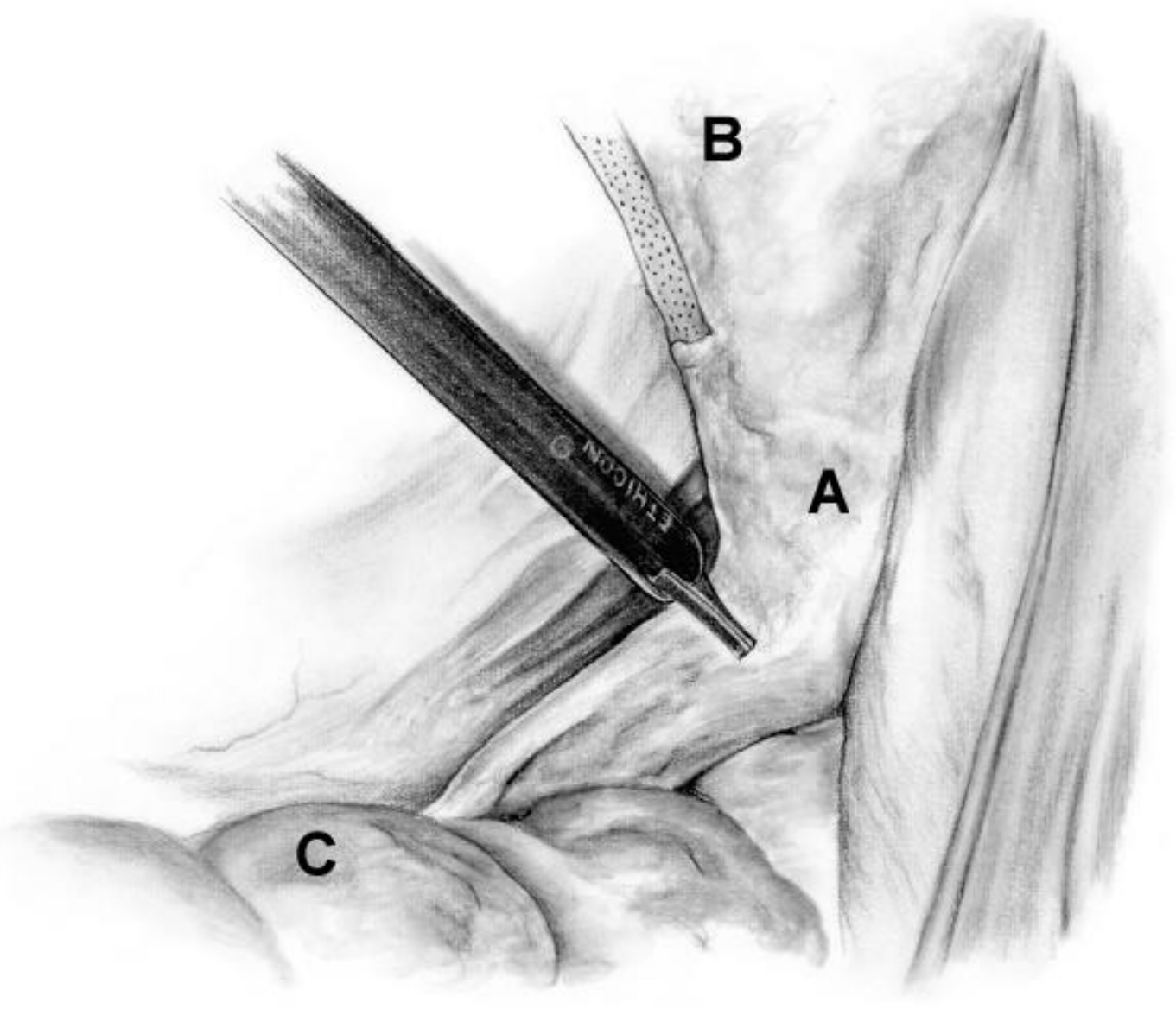

Figure 6. Application of the Harmonic Scalpeltransection of the mesometrium $(A)$; note the staples on the transection line of the mesovarium (B); descending colon (C) 


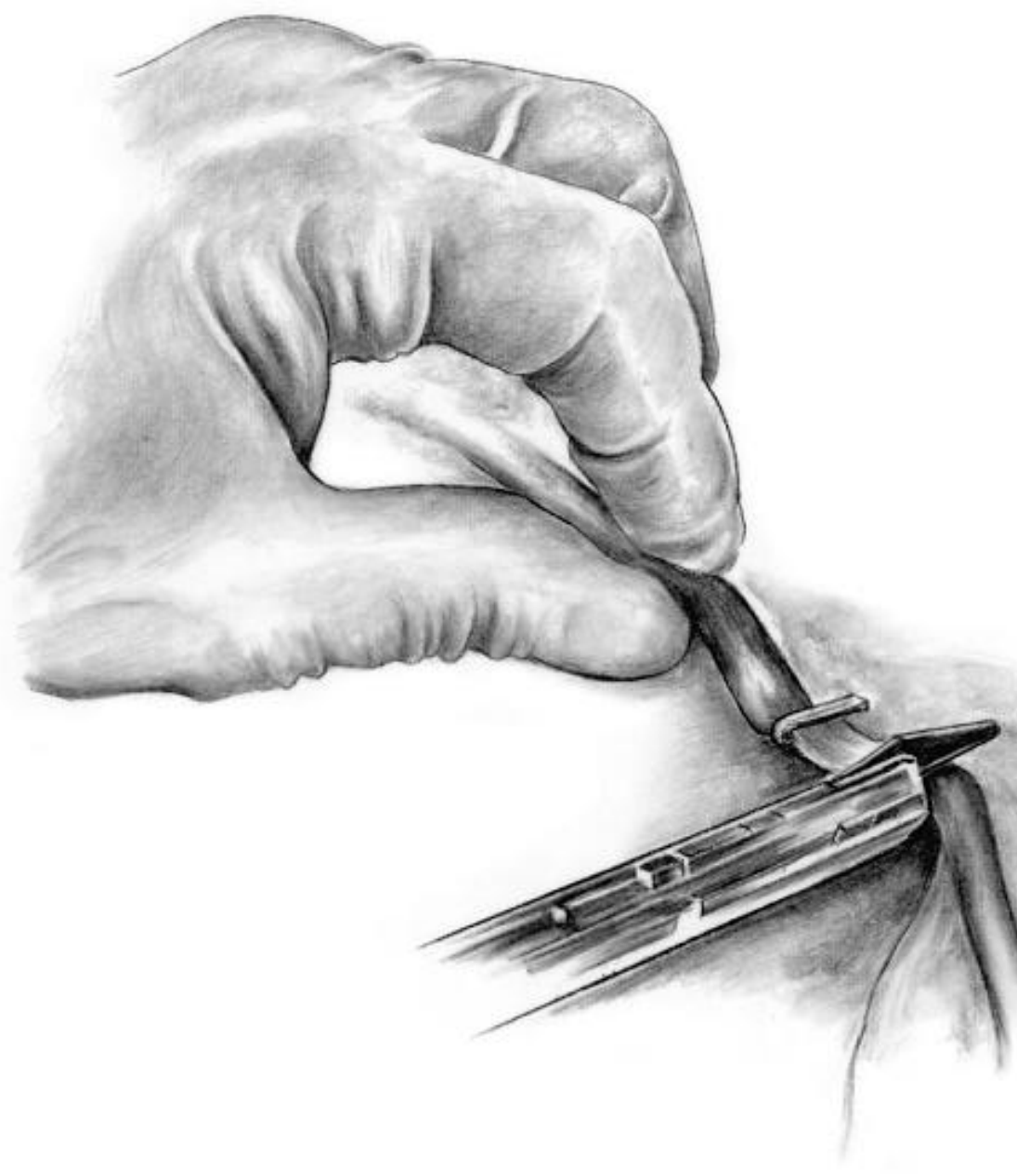

Figure 7. Application of the endoscopic clips - skeletonized large vessel within the mesometrium prior to transection 


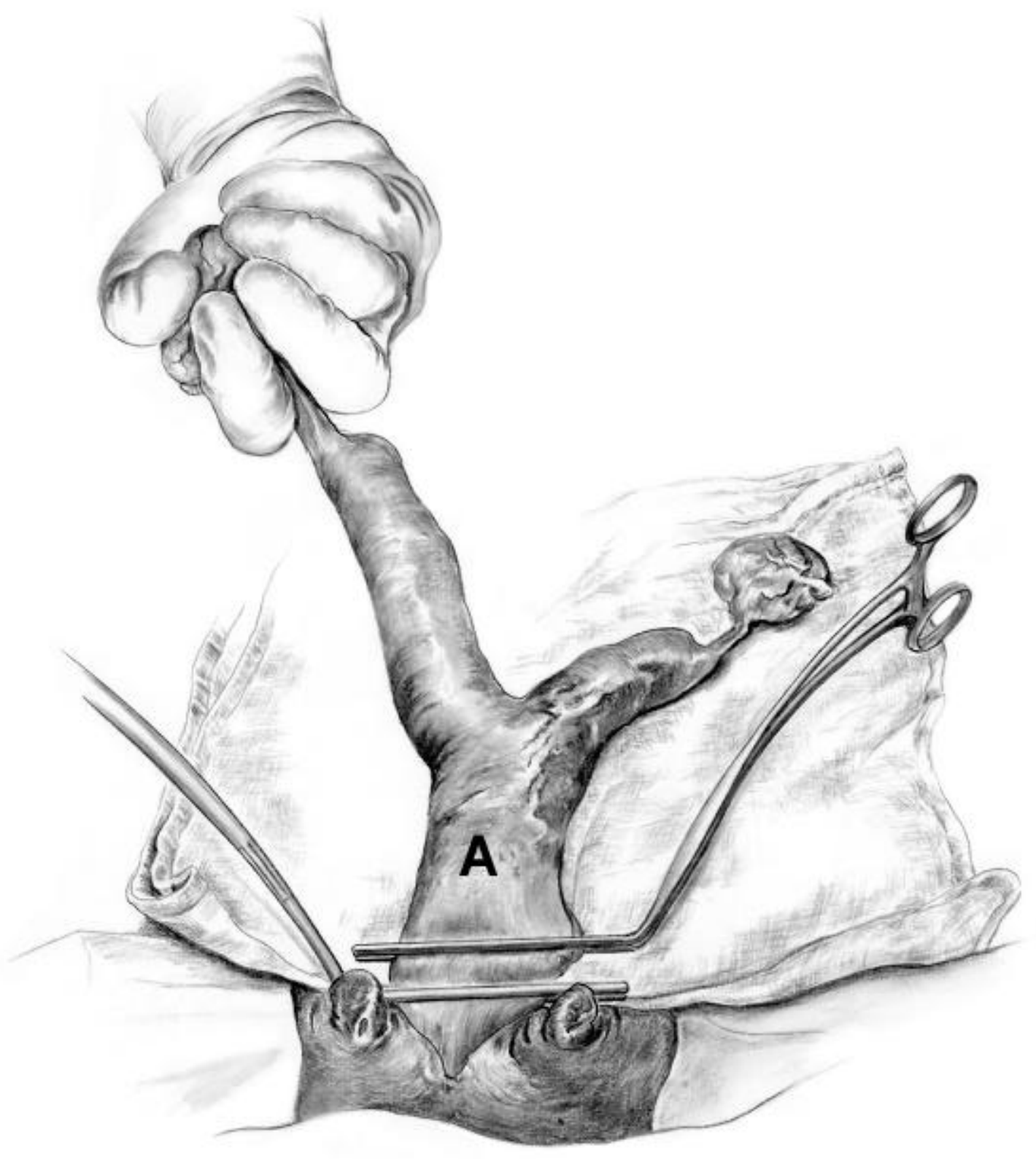

Figure 8. Exteriorized genital tract - placement of 2 large Carmalt forceps at the most caudal accessible extent of the exteriorized uterus; note the uterine body (A), the right ovary is held by the surgeon 


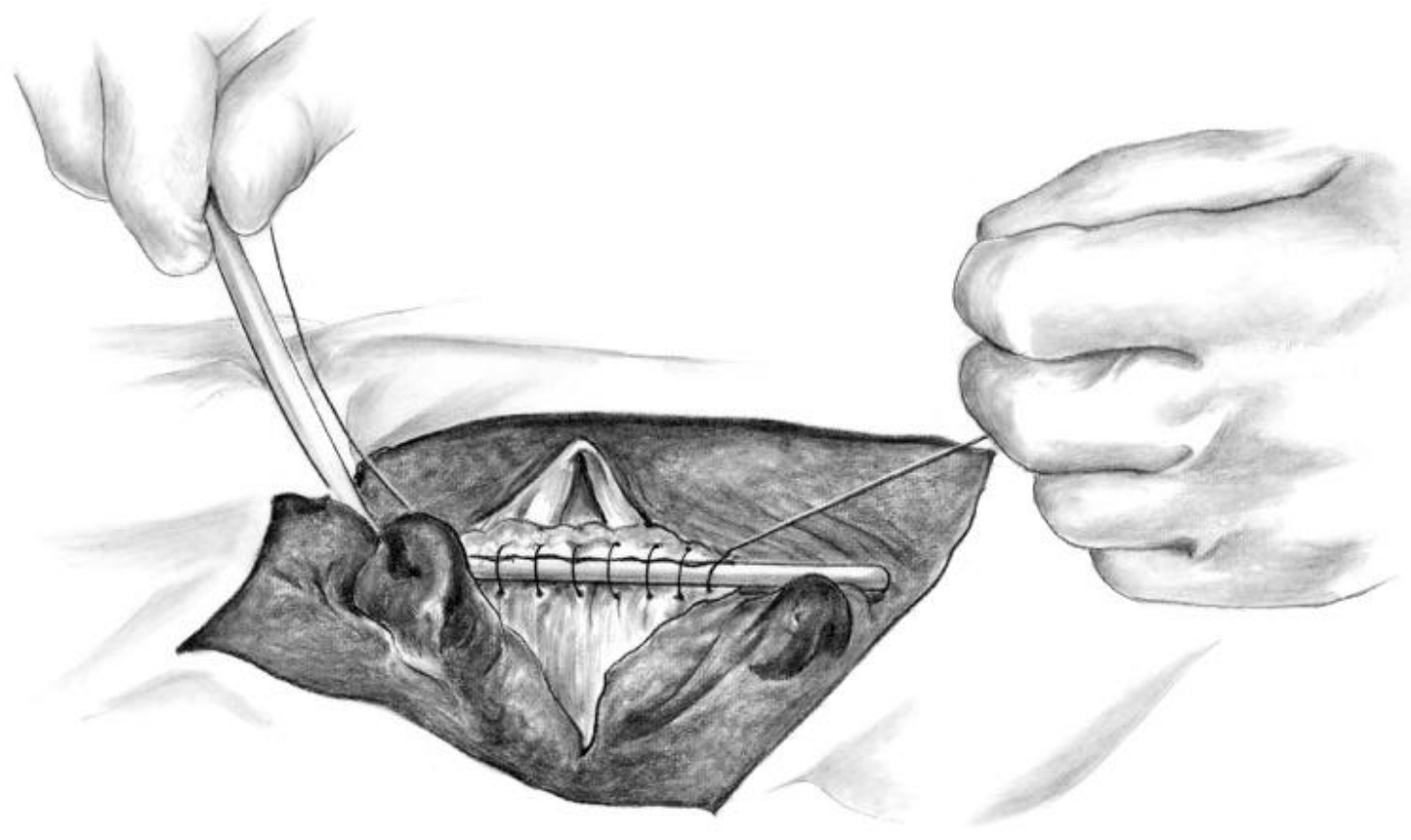

Figure 9. Closure of the uterine stump - using a no. 1 polydioxanone suture in a Parker-Kerr pattern 


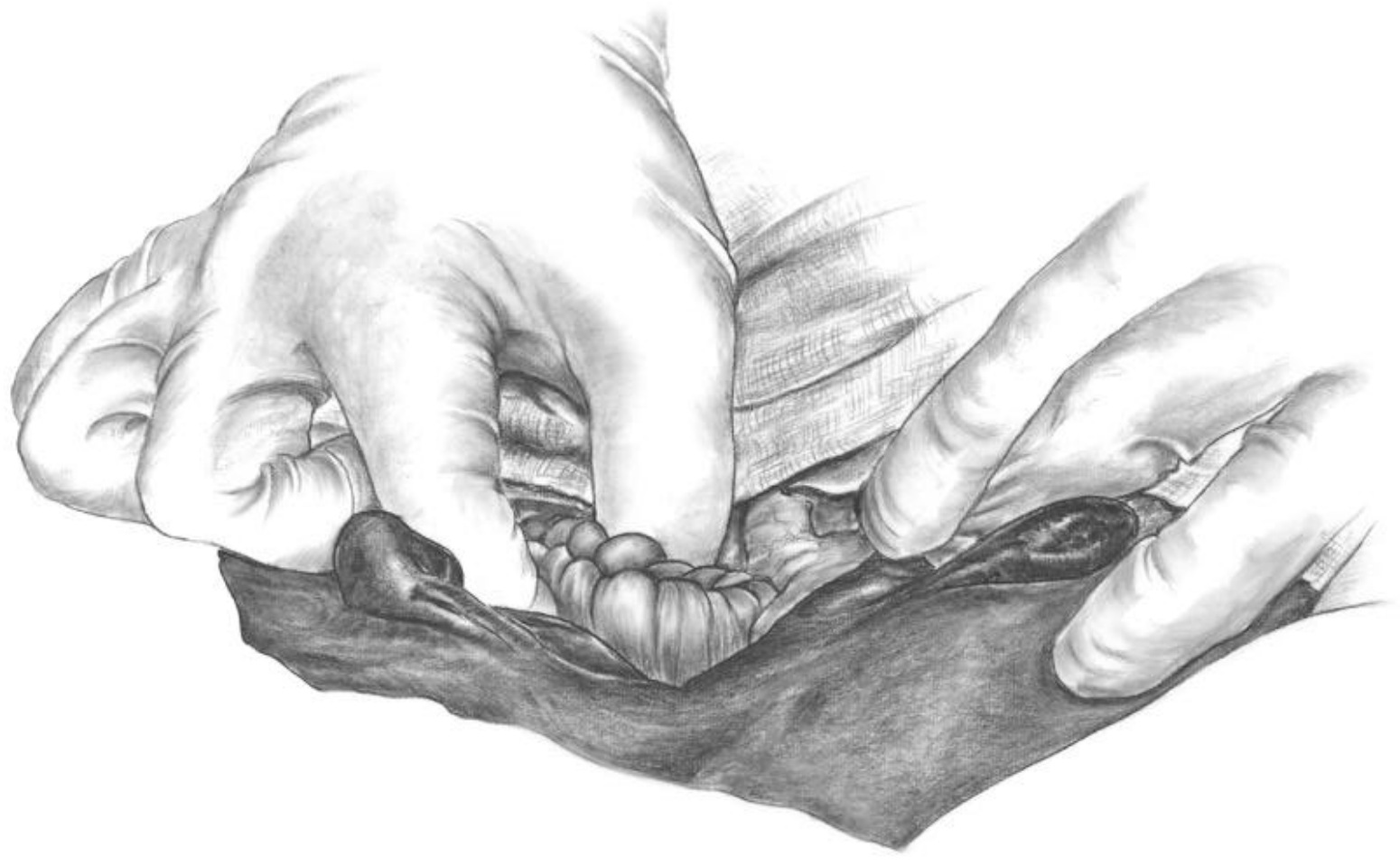

Figure 10. Completed closure of the uterine remnant 
Table 8-1: Anamnesis of the experimental horses

\begin{tabular}{|l|l|l|l|l|l|l|}
\hline \multirow{2}{*}{} & \multicolumn{9}{|l}{ Mare no. } & $\mathbf{1}$ & $\mathbf{2}$ & $\mathbf{3}$ & $\mathbf{4}$ & $\mathbf{5}$ & $\mathbf{6}$ \\
\hline Age (years) & 11 & 14 & 24 & 22 & 11 & 22 \\
\hline Weight (kg) & 442 & 567 & 553 & 504 & 509 & 522 \\
\hline Breed & QH & TB & TB & TB & TB & TB \\
\hline Parity & 0 & multiple & unknown & multiple & multiple & multiple \\
\hline $\begin{array}{l}\text { Estrus at the } \\
\text { time of } \\
\text { surgery }\end{array}$ & no & no & no & no & yes & yes \\
\hline
\end{tabular}


Table 8-2: Preoperative complete blood count values of the experimental horses

\begin{tabular}{|l|l|l|l|l|l|l|}
\hline & \multicolumn{7}{|l}{ Mare no. } \\
\cline { 2 - 7 } & $\mathbf{1}$ & $\mathbf{2}$ & $\mathbf{3}$ & $\mathbf{4}$ & $\mathbf{5}$ & $\mathbf{6}$ \\
\hline Erythrocytes $\left(\times 10^{6} / \mathrm{l}\right)$ & 7.51 & 8.4 & 6.84 & 8.02 & 8.11 & 8.59 \\
\hline Hemoglobin $(\mathrm{g} / \mathrm{dl})$ & 12.8 & 15.3 & 11.6 & 13.9 & 13.8 & 15.0 \\
\hline Hematocrit $(\%)$ & 35.0 & 41.2 & 32.0 & 38.7 & 37.2 & 42.1 \\
\hline Total protein $(\mathrm{g} / \mathrm{dl})$ & 7.5 & 8.5 & 7.6 & 6.7 & 7.5 & 7.0 \\
\hline White blood cell $\left(\times 10^{3} / \mu \mathrm{l}\right)$ & 8.58 & 13.1 & 7.67 & 6.86 & 9.78 & 7.67 \\
\hline Neutrophiles $\left(\times 10^{3} / \mu \mathrm{l}\right)$ & 4.976 & 9.563 & 4.985 & 3.842 & 6.944 & 4.985 \\
\hline Bands $\left(\times 10^{3} / \mu \mathrm{l}\right)$ & 0 & 0 & 0 & 0 & 0 & 0 \\
\hline Lymphocytes $\left(\times 10^{3} / \mu \mathrm{l}\right)$ & 2.746 & 2.489 & 2.148 & 2.538 & 1.858 & 2.224 \\
\hline Monocytes $\left(\times 10^{3} / \mu \mathrm{l}\right)$ & 0.257 & 0.655 & 0.077 & 0.069 & 0.098 & 0.307 \\
\hline Eosinophiles $\left(\times 10^{3} / \mu \mathrm{l}\right)$ & 0.515 & 0.393 & 0.384 & 0.412 & 0.782 & 0.153 \\
\hline Basophiles $\left(\times 10^{3} / \mu \mathrm{l}\right)$ & 0.086 & 0 & 0.077 & 0 & 0.098 & 0 \\
\hline Platelet count $\left(\times 10^{-3} / \mathrm{l}\right)$ & 173 & 139 & 184 & 180 & 167 & 169 \\
\hline Fibrinogen $(\mathrm{mg} / \mathrm{dl})$ & 200 & 100 & 300 & 300 & 300 & 400 \\
\hline
\end{tabular}


Table 8-3: Preoperative clinical blood chemistry values of the experimental horses

\begin{tabular}{|c|c|c|c|c|c|c|}
\hline & \multicolumn{6}{|c|}{ Mare no. } \\
\hline & 1 & 2 & 3 & 4 & 5 & 6 \\
\hline Glucose (mg/dl) & 83 & 101 & 109 & 107 & 110 & 127 \\
\hline BUN (mg/dl) & 18 & 17 & 20 & 21 & 26 & 16 \\
\hline Creatinine $(\mathrm{mg} / \mathrm{dl})$ & 1.6 & 1.1 & 1.2 & 1.3 & 1.5 & 1.5 \\
\hline Phosphorous (mg/dl) & 2.9 & 2.8 & 1.9 & 2.4 & 1.8 & 3.5 \\
\hline Calcium (mg/dl) & 11.9 & 11.8 & 12.2 & 11.2 & 12.2 & 12.1 \\
\hline Magnesium (mg/dl) & 1.7 & 1.5 & 1.5 & 1.7 & 2.2 & 1.5 \\
\hline Total protein $(\mathrm{g} / \mathrm{dl})$ & 6.9 & 8.3 & 7.3 & 6.1 & 7.2 & 6.5 \\
\hline Albumin (g/dl) & 3.7 & 3.0 & 3.3 & 3.1 & 3.1 & 3.6 \\
\hline Globulin (g/dl) & 3.2 & 5.3 & 4.0 & 3.0 & 4.1 & 2.9 \\
\hline AST (IU/I) & 412 & 238 & 251 & 258 & 185 & 319 \\
\hline GGT (IU/I) & 24 & 11 & 45 & 31 & 13 & 21 \\
\hline total Bilirubin (mg/dl) & 2.5 & 1.3 & 2.3 & 2.1 & 2.0 & 7.1 \\
\hline Creatine phosphokinase (IU/I) & 373 & 171 & 170 & 213 & 177 & 201 \\
\hline Sodium $(\mathrm{mEq} / \mathrm{l})$ & 138 & 132 & 137 & 131 & 139 & 138 \\
\hline Potassium (mEq/l) & 2.8 & 3.7 & 3.9 & 4.2 & 4.0 & 3.6 \\
\hline Chloride $(\mathrm{mEq} / \mathrm{l})$ & 102 & 99 & 102 & 101 & 103 & 105 \\
\hline
\end{tabular}


Table 8-4: Anesthetic aspects and parameters of the experimental horses

\begin{tabular}{|c|c|c|c|c|c|c|}
\hline & \multicolumn{6}{|l|}{ Mare no. } \\
\hline & 1 & 2 & 3 & 4 & 5 & 6 \\
\hline \multicolumn{7}{|l|}{ Induction } \\
\hline $\begin{array}{l}\text { Xylazine } \\
\text { hydrochloride }(\mathrm{mg} / \mathrm{kg})\end{array}$ & 0.8 & 0.5 & 1.2 & 1.1 & 1.1 & 1.1 \\
\hline $\begin{array}{l}\text { Ketamine } \\
\text { hydrochloride }(\mathrm{mg} / \mathrm{kg})\end{array}$ & 2.2 & 2.2 & 2.2 & 2.3 & 2.2 & 2.4 \\
\hline Guaifenesin (mg/kg) & 70 & 80 & 77 & 65 & 64 & 86 \\
\hline \multicolumn{7}{|l|}{ Maintenance } \\
\hline $\begin{array}{l}\text { Halothane / } \\
\text { Sevoflurane }\end{array}$ & $\mathrm{H}$ & $\mathrm{H}$ & $\mathrm{H}$ & $S$ & $S$ & $S$ \\
\hline $\begin{array}{l}\text { Butorphanol tartrate } \\
\text { (total dose) intra op }\end{array}$ & $\begin{array}{l}1 \times 8 \mathrm{mg} \\
1 \times 10 \mathrm{mg}\end{array}$ & $3 \times 11 \mathrm{mg}$ & $2 \times 11 \mathrm{mg}$ & $3 \times 10 \mathrm{mg}$ & $2 \times 10 \mathrm{mg}$ & $2 \times 10 \mathrm{mg}$ \\
\hline $\begin{array}{l}\text { Intra op } \\
\text { complications* }\end{array}$ & \begin{tabular}{|l|} 
hypo- \\
tension; \\
bradycar \\
dia; $2^{\circ}$ \\
AV block \\
\end{tabular} & $\begin{array}{l}\text { hypo- } \\
\text { tension; } \\
\text { VPC }\end{array}$ & $\begin{array}{l}\text { hypo- } \\
\text { tension }\end{array}$ & $\begin{array}{l}\text { hypo- } \\
\text { tension }\end{array}$ & $\begin{array}{l}\text { hypo- } \\
\text { tension }\end{array}$ & $\begin{array}{l}\text { hypo- } \\
\text { tension }\end{array}$ \\
\hline Surgery time (min) & \begin{tabular}{|l|}
210 \\
\end{tabular} & 185 & 150 & 200 & 150 & 165 \\
\hline \multicolumn{7}{|l|}{ Recovery } \\
\hline $\begin{array}{l}\text { Xylazine } \\
\text { (total dose in mg) }\end{array}$ & 100 & 50 & \begin{tabular}{|l|} 
amount \\
not \\
recorded
\end{tabular} & 100 & 100 & 100 \\
\hline Recovery quality & good & rough & $\begin{array}{l}\text { fractured } \\
\text { femur }\end{array}$ & good & good & rough \\
\hline Recovery time (min) & 45 & 100 & N/A & 40 & 90 & 90 \\
\hline
\end{tabular}

* hypotension MAP $<70 \mathrm{mmHg}$, always responding to $1-5 \mu \mathrm{g} / \mathrm{kg} / \mathrm{min}$ dobutamine bradycardia pulse rate $<20 \mathrm{bpm}$ $2^{\circ}$ atrioventricular block

VPC - ventricular premature contractions 
Table 8-5: Surgical aspects and parameters of the experimental horses

\begin{tabular}{|l|l|l|l|l|l|l|}
\hline \multicolumn{7}{|l|}{ Mare no. } \\
\cline { 2 - 7 } & $\mathbf{1}$ & $\mathbf{2}$ & $\mathbf{3}$ & $\mathbf{4}$ & $\mathbf{5}$ & $\mathbf{6}$ \\
\hline $\begin{array}{l}50 \mathrm{~mm} \text { vs. } 80 \mathrm{~mm} \\
\text { Omniport device }\end{array}$ & 80 & 80 & 50 & 80 & 50 & 80 \\
\hline Hemorrhage & \multicolumn{5}{l|}{} \\
\hline Left mesovarium & none & none & none & none & none & none \\
\hline Left mesometrium & $\begin{array}{l}\text { minimal, } \\
\text { applied } \\
\text { clips }\end{array}$ & $\begin{array}{l}\text { none, } \\
\text { clips pre- } \\
\text { emptive }\end{array}$ & $\begin{array}{l}\text { none, } \\
\text { clips pre- } \\
\text { emptive }\end{array}$ & $\begin{array}{l}\text { mo- } \\
\text { derate, } \\
\text { applied } \\
\text { clips }\end{array}$ & $\begin{array}{l}\text { minimal, } \\
\text { applied } \\
\text { clips }\end{array}$ & $\begin{array}{l}\text { none, } \\
\text { clips pre- } \\
\text { emptive }\end{array}$ \\
\hline Right mesovarium & none & none & none & none & none & none \\
\hline Right mesometrium & none & $\begin{array}{l}\text { none, } \\
\text { clips pre- } \\
\text { emptive }\end{array}$ & none & $\begin{array}{l}\text { minimal, } \\
\text { applied } \\
\text { clips }\end{array}$ & none & none \\
\hline $\begin{array}{l}\text { Ligation of the } \\
\text { caudal uterine artery } \\
\text { after exteriorization }\end{array}$ & none & none & right side & right side & right side & none \\
\hline
\end{tabular}


Table 8-6: Wound healing and other postoperative findings of the experimental horses

\begin{tabular}{|c|l|l|l|}
\hline $\begin{array}{c}\text { Mare } \\
\text { no. }\end{array}$ & Wound healing & $\begin{array}{l}\text { Serosanguineous } \\
\text { vulvar discharge }\end{array}$ & $\begin{array}{l}\text { First } \\
\text { defecation }\end{array}$ \\
\hline $\mathbf{1}$ & $\begin{array}{l}\text { slight hemorrhage from umbilical portal; } \\
\text { hemorrhage stopped within } 12 \mathrm{~h}\end{array}$ & day 1 - 3 post op & within $12 \mathrm{~h}$ \\
\hline $\mathbf{2}$ & slight ventral edema - resolved & day 1 - 5 post op & within $6 \mathrm{~h}$ \\
\hline $\mathbf{3}$ & N/A & N/A & N/A \\
\hline $\mathbf{4}$ & $\begin{array}{l}\text { slight udder swelling; } \\
\text { moderate ventral edema }\end{array}$ & none & within $6 \mathrm{~h}$ \\
\hline $\mathbf{5}$ & $\begin{array}{l}\text { right portal slight swelling (hematoma) - } \\
\text { resolved; } \\
\text { laparotomy tender to the touch }\end{array}$ & day 1 - 2 post op & within $12 \mathrm{~h}$ \\
\hline $\mathbf{6}$ & $\begin{array}{l}\text { right portal slight swelling (hematoma) - } \\
\text { resolved; } \\
\text { laparotomy purulent discharge 13 } \\
\text { op day; } \\
\text { moderate ventral edema }\end{array}$ & day 1 post op & within $12 \mathrm{~h}$ \\
\hline
\end{tabular}


Table 8-7: Preoperative and postoperative pulse rate values of the experimental horses

\begin{tabular}{|c|c|c|c|c|c|c|}
\hline & $\mathrm{Ma}$ & & & & & \\
\hline $\begin{array}{l}\text { Pulse rate } \\
\text { (beats/min) }\end{array}$ & 1 & 2 & 3 & 4 & 5 & 6 \\
\hline Preoperative & 30 & 40 & 34 & 40 & 34 & 32 \\
\hline $\begin{array}{l}1^{\text {st }}-8^{\text {th }} h \\
\text { post op a }\end{array}$ & 48 & $59^{(1)}$ & $\mathrm{N} / \mathrm{A}$ & 54 & 37 & 47 \\
\hline $1^{\text {st }} d$ post op ${ }^{b}$ & 41 & 54 & $\mathrm{~N} / \mathrm{A}$ & 69 & 35 & 43 \\
\hline $2^{\text {nd }} d$ post op ${ }^{c}$ & 33 & 44 & $\mathrm{~N} / \mathrm{A}$ & 64 & 32 & 37 \\
\hline $3^{\text {rd }} d$ post op ${ }^{c}$ & 34 & 48 & $\mathrm{~N} / \mathrm{A}$ & 58 & 34 & $40^{(3)}$ \\
\hline $4^{\text {th }}$ d post op ${ }^{c}$ & 30 & 48 & $\mathrm{~N} / \mathrm{A}$ & 50 & 36 & $40^{(3)}$ \\
\hline $5^{\text {th }} d$ post op ${ }^{c}$ & 30 & 44 & $\mathrm{~N} / \mathrm{A}$ & $54^{(2)}$ & 36 & $42^{(3)}$ \\
\hline $6^{\text {th }}$ d post op ${ }^{c}$ & 34 & 44 & $\mathrm{~N} / \mathrm{A}$ & $50^{(2)}$ & 36 & 40 \\
\hline $7^{\text {th }} \mathrm{d}$ post op ${ }^{\mathrm{c}}$ & 38 & 41 & $\mathrm{~N} / \mathrm{A}$ & $80^{(2)}$ & 35 & 35 \\
\hline $8^{\text {th }}$ d post op & 36 & 48 & $\mathrm{~N} / \mathrm{A}$ & $72^{(2)}$ & 36 & 36 \\
\hline $9^{\text {th }} d$ post op & 40 & 40 & $\mathrm{~N} / \mathrm{A}$ & $96^{(2)}$ & 32 & 36 \\
\hline $10^{\text {th }} \mathrm{d}$ post op & 44 & 40 & $\mathrm{~N} / \mathrm{A}$ & $84^{(2)}$ & 40 & 32 \\
\hline $11^{\text {th }} d$ post op & 36 & 40 & $\mathrm{~N} / \mathrm{A}$ & $84^{(2)}$ & 32 & 36 \\
\hline $12^{\text {th }} \mathrm{d}$ post op & 40 & 36 & $\mathrm{~N} / \mathrm{A}$ & $\mathrm{N} / \mathrm{A}$ & 36 & 32 \\
\hline $13^{\text {th }} \mathrm{d}$ post op & 40 & 40 & $\mathrm{~N} / \mathrm{A}$ & $\mathrm{N} / \mathrm{A}$ & 36 & 36 \\
\hline $14^{\text {th }} \mathrm{d}$ post op & 36 & 40 & $\mathrm{~N} / \mathrm{A}$ & $\mathrm{N} / \mathrm{A}$ & 36 & 32 \\
\hline
\end{tabular}

${ }^{a}$ mean value of hourly evaluation

${ }^{\mathrm{b}}$ mean value of evaluation $\mathrm{q} 6 \mathrm{~h}$

${ }^{c}$ mean value of the morning and evening evaluation

(1) Pulse rate $68 \mathrm{bpm}$ at $5 \mathrm{~h}$ post op, responded to a dose of $100 \mathrm{mg}$ xylazine

(2) Temp. up to $104.2^{\circ} \mathrm{F}$, pulse rate up to $100 \mathrm{bpm}$ and respiration rate up to $56 \mathrm{bpm}$ from the $4^{\text {th }}$ post op day on, $1.1 \mathrm{mg} / \mathrm{kg}$ flunixin meglumine $\mathrm{qd}$, and $22,000 \mathrm{U} / \mathrm{kg}$ BID procaine penicillin

(3) intermittent pyrexia $\left(<102^{\circ} \mathrm{F}\right) 3^{\text {rd }}$ to $5^{\text {th }}$ post op day, 1.1 to $0.5 \mathrm{mg} / \mathrm{kg}$ qd flunixin meglumine 
Table 8-8: Preoperative and postoperative respiration rate values of the experimental horses

\begin{tabular}{|c|c|c|c|c|c|c|}
\hline \multirow[b]{2}{*}{$\begin{array}{l}\text { Respiration } \\
\text { rate } \\
\text { (breaths/min) }\end{array}$} & \multicolumn{6}{|c|}{ Mare no. } \\
\hline & 1 & 2 & 3 & 4 & 5 & 6 \\
\hline Preoperative & 16 & 24 & 19 & 21 & 14 & 12 \\
\hline $\begin{array}{l}1^{\text {st }}-8^{\text {th }} h \\
\text { post op a }\end{array}$ & 26 & $40^{(1)}$ & $\mathrm{N} / \mathrm{A}$ & 42 & 18 & 36 \\
\hline $1^{\text {st }} d$ post op & 24 & 30 & $\mathrm{~N} / \mathrm{A}$ & 27 & 18 & 31 \\
\hline $2^{\text {nd }} d$ post op ${ }^{c}$ & 13 & 36 & $\mathrm{~N} / \mathrm{A}$ & 21 & 16 & 24 \\
\hline $3^{\text {rd }} d$ post op ${ }^{c}$ & 14 & 36 & $\mathrm{~N} / \mathrm{A}$ & 16 & 14 & $22^{(3)}$ \\
\hline $4^{\text {th }} d$ post op ${ }^{c}$ & 18 & 30 & $\mathrm{~N} / \mathrm{A}$ & 16 & 14 & $20^{(3)}$ \\
\hline $5^{\text {th }} d$ post op ${ }^{c}$ & 14 & 24 & $\mathrm{~N} / \mathrm{A}$ & $38^{(2)}$ & 16 & $18^{(3)}$ \\
\hline $6^{\text {th }}$ d post op ${ }^{c}$ & 18 & 28 & $\mathrm{~N} / \mathrm{A}$ & $26^{(2)}$ & 16 & 20 \\
\hline $7^{\text {th }}$ d post op ${ }^{c}$ & 15 & 20 & $\mathrm{~N} / \mathrm{A}$ & $38^{(2)}$ & 16 & 17 \\
\hline $8^{\text {th }} d$ post op & 12 & 20 & $\mathrm{~N} / \mathrm{A}$ & $25^{(2)}$ & 16 & 16 \\
\hline $9^{\text {th }} d$ post op & 12 & 16 & $\mathrm{~N} / \mathrm{A}$ & $32^{(2)}$ & 16 & 16 \\
\hline $10^{\text {th }} \mathrm{d}$ post op & 20 & 16 & $\mathrm{~N} / \mathrm{A}$ & $52^{(2)}$ & 16 & 16 \\
\hline $11^{\text {th }} d$ post op & 16 & 20 & $\mathrm{~N} / \mathrm{A}$ & $48^{(2)}$ & 16 & 12 \\
\hline $12^{\text {th }} \mathrm{d}$ post op & 20 & 16 & $\mathrm{~N} / \mathrm{A}$ & $\mathrm{N} / \mathrm{A}$ & 16 & 16 \\
\hline $13^{\text {th }} d$ post op & 24 & 20 & $\mathrm{~N} / \mathrm{A}$ & $\mathrm{N} / \mathrm{A}$ & 16 & 20 \\
\hline $14^{\text {th }} \mathrm{d}$ post op & 24 & 20 & $\mathrm{~N} / \mathrm{A}$ & $\mathrm{N} / \mathrm{A}$ & 16 & 20 \\
\hline
\end{tabular}

${ }^{a}$ mean value of hourly evaluation

${ }^{b}$ mean value of evaluation $q 6 h$

${ }^{c}$ mean value of the morning and evening evaluation

(1) Pulse rate $68 \mathrm{bpm}$ at $5 \mathrm{~h}$ post op, responded to a dose of $100 \mathrm{mg}$ xylazine

(2) Temp. up to $104.2^{\circ} \mathrm{F}$, pulse rate up to $100 \mathrm{bpm}$ and respiration rate up to $56 \mathrm{bpm}$ from the $4^{\text {th }}$ post op day on, $1.1 \mathrm{mg} / \mathrm{kg}$ flunixin meglumine $\mathrm{qd}$, and $22,000 \mathrm{U} / \mathrm{kg}$ BID procaine penicillin

(3) intermittent pyrexia $\left(<102^{\circ} \mathrm{F}\right) 3^{\text {rd }}$ to $5^{\text {th }}$ post op day, 1.1 to $0.5 \mathrm{mg} / \mathrm{kg}$ qd flunixin meglumine 
Table 8-9: Preoperative and postoperative body temperature values of the experimental horses

\begin{tabular}{|c|c|c|c|c|c|c|}
\hline \multirow[b]{2}{*}{$\begin{array}{l}\text { Body } \\
\text { temperature } \\
\left({ }^{\circ} \mathrm{F}\right)\end{array}$} & \multicolumn{6}{|c|}{ Mare no. } \\
\hline & 1 & 2 & 3 & 4 & 5 & 6 \\
\hline Preoperative & 99.2 & 99.2 & 100.1 & 99.1 & 99.2 & 99.9 \\
\hline $\begin{array}{l}1^{\text {st }}-8^{\text {th }} h \\
\text { post op a }\end{array}$ & 101.4 & $100.2^{(1)}$ & $\mathrm{N} / \mathrm{A}$ & 99.8 & 99.8 & 100.4 \\
\hline $1^{\text {st }} d$ post op & 99.9 & 100.9 & $\mathrm{~N} / \mathrm{A}$ & 99.8 & 100.6 & 100.7 \\
\hline $2^{\text {nd }} d$ post op ${ }^{c}$ & 100.0 & 100.2 & $\mathrm{~N} / \mathrm{A}$ & 99.5 & 99.1 & 101.2 \\
\hline $3^{\text {rd }} d$ post op ${ }^{c}$ & 99.9 & 100.2 & $\mathrm{~N} / \mathrm{A}$ & 99.1 & 100.0 & $100.4^{(3)}$ \\
\hline $4^{\text {th }} d$ post op ${ }^{c}$ & 99.8 & 99.6 & $\mathrm{~N} / \mathrm{A}$ & 101.0 & 100.1 & $101.2^{(3)}$ \\
\hline $5^{\text {th }} d$ post op ${ }^{c}$ & 99.8 & 99.5 & $\mathrm{~N} / \mathrm{A}$ & $103.0^{(2)}$ & 100.2 & $101.1^{(3)}$ \\
\hline $6^{\text {th }}$ d post op ${ }^{c}$ & 99.7 & 100.1 & $\mathrm{~N} / \mathrm{A}$ & $101.4^{(2)}$ & 100.2 & 100.5 \\
\hline $7^{\text {th }} d$ post op ${ }^{c}$ & 99.9 & 99.3 & $\mathrm{~N} / \mathrm{A}$ & $102.4^{(2)}$ & 100.3 & 99.4 \\
\hline $8^{\text {th }}$ d post op & 99.6 & 99.0 & $\mathrm{~N} / \mathrm{A}$ & $102.4^{(2)}$ & 100.4 & 99.5 \\
\hline $9^{\text {th }} d$ post op & 101.0 & 98.5 & $\mathrm{~N} / \mathrm{A}$ & $102.6^{(2)}$ & 99.9 & 99.0 \\
\hline $10^{\text {th }} \mathrm{d}$ post op & 100.5 & 99.6 & $\mathrm{~N} / \mathrm{A}$ & $102.3^{(2)}$ & 100.9 & 99.0 \\
\hline $11^{\text {th }} d$ post op & 99.1 & 100.0 & $\mathrm{~N} / \mathrm{A}$ & $102.2^{(2)}$ & 99.9 & 100.0 \\
\hline $12^{\text {th }} \mathrm{d}$ post op & 99.8 & 98.9 & $\mathrm{~N} / \mathrm{A}$ & $\mathrm{N} / \mathrm{A}$ & 100.1 & 99.4 \\
\hline $13^{\text {th }} d$ post op & 99.9 & 99.0 & $\mathrm{~N} / \mathrm{A}$ & $\mathrm{N} / \mathrm{A}$ & 100.3 & 99.4 \\
\hline $14^{\text {th }} \mathrm{d}$ post op & 99.3 & 99.0 & $\mathrm{~N} / \mathrm{A}$ & $\mathrm{N} / \mathrm{A}$ & 100.1 & 98.6 \\
\hline
\end{tabular}

${ }^{a}$ mean value of hourly evaluation

${ }^{b}$ mean value of evaluation $\mathrm{q} 6 \mathrm{~h}$

${ }^{c}$ mean value of the morning and evening evaluation

(1) Pulse rate $68 \mathrm{bpm}$ at $5 \mathrm{~h}$ post op, responded to a dose of $100 \mathrm{mg}$ xylazine

(2) Temp. up to $104.2^{\circ} \mathrm{F}$, pulse rate up to $100 \mathrm{bpm}$ and respiration rate up to $56 \mathrm{bpm}$ from the $4^{\text {th }}$ post op day on, $1.1 \mathrm{mg} / \mathrm{kg}$ flunixin meglumine qd, and $22,000 \mathrm{U} / \mathrm{kg}$ BID procaine penicillin

${ }^{(3)}$ intermittent pyrexia $\left(<102^{\circ} \mathrm{F}\right) 3^{\text {rd }}$ to $5^{\text {th }}$ post op day, 1.1 to $0.5 \mathrm{mg} / \mathrm{kg}$ qd flunixin meglumine 
Table 8-10: Preoperative and postoperative general attitude of the experimental horses

\begin{tabular}{|c|c|c|c|c|c|c|}
\hline \multirow[b]{2}{*}{ Attitude } & \multicolumn{6}{|c|}{ Mare no. } \\
\hline & 1 & 2 & 3 & 4 & 5 & 6 \\
\hline Preoperative & BAR & BAR & BAR & BAR & BAR & BAR \\
\hline $\begin{array}{l}1^{\text {st }}-8^{\text {th }} h \\
\text { post op }\end{array}$ & QAR & QAR $^{1}$ & $\mathrm{~N} / \mathrm{A}$ & QAR & BAR & QAR \\
\hline $1^{\text {st }} d$ post op. ${ }^{b}$ & QAR & BAR & $\mathrm{N} / \mathrm{A}$ & depr. & BAR & BAR \\
\hline $2^{\text {nd }} d$ post op. ${ }^{c}$ & BAR & BAR & N/A & depr. & BAR & BAR \\
\hline 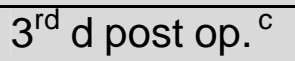 & BAR & BAR & $N / A$ & depr. & BAR & QAR $^{3}$ \\
\hline $4^{\text {th }}$ d post op. ${ }^{c}$ & BAR & BAR & $\mathrm{N} / \mathrm{A}$ & depr. & BAR & $\mathrm{QAR}^{3}$ \\
\hline $5^{\text {th }}$ d post op. ${ }^{c}$ & BAR & BAR & $\mathrm{N} / \mathrm{A}$ & depr. $^{2}$ & BAR & $\mathrm{BAR}^{3}$ \\
\hline $6^{\text {th }}$ d post op. ${ }^{c}$ & BAR & BAR & $N / A$ & depr. ${ }^{2}$ & BAR & BAR \\
\hline $7^{\text {th }}$ d post op. ${ }^{c}$ & BAR & BAR & $\mathrm{N} / \mathrm{A}$ & depr. $^{2}$ & BAR & BAR \\
\hline $8^{\text {th }}$ d post op. & BAR & BAR & $\mathrm{N} / \mathrm{A}$ & depr. $^{2}$ & BAR & BAR \\
\hline $9^{\text {th }}$ d post op. & BAR & BAR & $\mathrm{N} / \mathrm{A}$ & depr. $^{2}$ & BAR & BAR \\
\hline $10^{\text {th }} \mathrm{d}$ post op. & BAR & BAR & N/A & depr. $^{2}$ & BAR & BAR \\
\hline $11^{\text {th }} \mathrm{d}$ post op. & BAR & BAR & $\mathrm{N} / \mathrm{A}$ & depr. $^{2}$ & BAR & BAR \\
\hline $12^{\text {th }} \mathrm{d}$ post op. & BAR & BAR & $\mathrm{N} / \mathrm{A}$ & $\mathrm{N} / \mathrm{A}$ & BAR & BAR \\
\hline $13^{\text {th }} d$ post op. & BAR & BAR & $\mathrm{N} / \mathrm{A}$ & $\mathrm{N} / \mathrm{A}$ & BAR & BAR \\
\hline $14^{\text {th }} \mathrm{d}$ post op. & BAR & BAR & $\mathrm{N} / \mathrm{A}$ & $\mathrm{N} / \mathrm{A}$ & BAR & BAR \\
\hline
\end{tabular}

\footnotetext{
${ }^{a}$ mean value of hourly evaluation

${ }^{\mathrm{b}}$ mean value of evaluation $\mathrm{q} 6 \mathrm{~h}$

${ }^{c}$ mean value of the morning and evening evaluation

$\mathrm{BAR}=$ bright, alert, responsive

QAR = quiet, alert, responsive

depr. $=$ depressed

$1=$ mare showed signs of discomfort, and received additional $100 \mathrm{mg}$ xylazine IV

${ }^{2}=$ horse received additional $1.1 \mathrm{mg} / \mathrm{kg}$ flunixin meglumine $\mathrm{qd}, 22,000 \mathrm{U} / \mathrm{kg}$ procaine penicillin BID

${ }^{3}=$ horse received additional 0.5 to $1.1 \mathrm{mg} / \mathrm{kg}$ flunixin meglumine $\mathrm{qd}$
} 
Table 8-11: Preoperative and postoperative borborygmi of the experimental horses

\begin{tabular}{|c|c|c|c|c|c|c|}
\hline & Mare no & & & & & \\
\hline Borborygmi & 1 & 2 & 3 & 4 & 5 & 6 \\
\hline Preoperative & $\mathrm{N}$ & $\mathrm{N}$ & $\mathrm{N}$ & $\mathrm{N}$ & $\mathrm{N}$ & $\mathrm{N}$ \\
\hline $\begin{array}{l}1^{\text {st }}-8^{\text {th }} h \\
\text { post op }\end{array}$ & sl. decr. & sl. decr. ${ }^{1}$ & N/A & sl. decr. & sl. decr. & $\mathrm{N}$ \\
\hline $1^{\text {st }} d$ post op. ${ }^{b}$ & $\mathrm{~N}$ & $\mathrm{~N}$ & $\mathrm{~N} / \mathrm{A}$ & sev. decr. & $N$ & $\mathrm{~N}$ \\
\hline $2^{\text {nd }} d$ post op. ${ }^{c}$ & $\mathrm{~N}$ & $\mathrm{~N}$ & $\mathrm{~N} / \mathrm{A}$ & sl.decr. & $N$ & sl. decr. \\
\hline 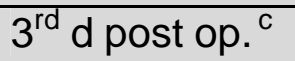 & $\mathrm{N}$ & $\mathrm{N}$ & N/A & $\mathrm{N}$ & $N$ & sl. decr. ${ }^{3}$ \\
\hline $4^{\text {th }}$ d post op. ${ }^{c}$ & $\mathrm{~N}$ & $\mathrm{~N}$ & $\mathrm{~N} / \mathrm{A}$ & $\mathrm{N}$ & $\mathrm{N}$ & sl. decr. ${ }^{3}$ \\
\hline $5^{\text {th }}$ d post op. ${ }^{c}$ & $\mathrm{~N}$ & $\mathrm{~N}$ & $\mathrm{~N} / \mathrm{A}$ & sl. decr. ${ }^{2}$ & $N$ & sl. decr. ${ }^{3}$ \\
\hline $6^{\text {th }}$ d post op. ${ }^{c}$ & $\mathrm{~N}$ & $\mathrm{~N}$ & N/A & sl. decr. ${ }^{2}$ & $N$ & $\mathrm{~N}$ \\
\hline $7^{\text {th }}$ d post op. ${ }^{c}$ & $\mathrm{~N}$ & $\mathrm{~N}$ & $\mathrm{~N} / \mathrm{A}$ & sl. decr. ${ }^{2}$ & $N$ & $\mathrm{~N}$ \\
\hline $8^{\text {th }}$ d post op. & $\mathrm{N}$ & $\mathrm{N}$ & $\mathrm{N} / \mathrm{A}$ & sl. decr. ${ }^{2}$ & $\mathrm{~N}$ & $\mathrm{~N}$ \\
\hline $9^{\text {th }}$ d post op. & $\mathrm{N}$ & $\mathrm{N}$ & $\mathrm{N} / \mathrm{A}$ & sl. decr. ${ }^{2}$ & $\mathrm{~N}$ & $\mathrm{~N}$ \\
\hline $10^{\text {th }} \mathrm{d}$ post op. & $\mathrm{N}$ & $\mathrm{N}$ & N/A & sl. decr. ${ }^{2}$ & $N$ & $\mathrm{~N}$ \\
\hline $11^{\text {th }} d$ post op. & $\mathrm{N}$ & $\mathrm{N}$ & N/A & sl. decr. ${ }^{2}$ & $N$ & $\mathrm{~N}$ \\
\hline $12^{\text {th }} \mathrm{d}$ post op. & $\mathrm{N}$ & $\mathrm{N}$ & $\mathrm{N} / \mathrm{A}$ & $\mathrm{N} / \mathrm{A}$ & $\mathrm{N}$ & $\mathrm{N}$ \\
\hline $13^{\text {th }} d$ post op. & $\mathrm{N}$ & $\mathrm{N}$ & N/A & $\mathrm{N} / \mathrm{A}$ & $\mathrm{N}$ & $\mathrm{N}$ \\
\hline $14^{\text {th }} \mathrm{d}$ post op. & $\mathrm{N}$ & $\mathrm{N}$ & $\mathrm{N} / \mathrm{A}$ & $\mathrm{N} / \mathrm{A}$ & $\mathrm{N}$ & $\mathrm{N}$ \\
\hline
\end{tabular}

\footnotetext{
${ }^{a}$ mean value of hourly evaluation

${ }^{\mathrm{b}}$ mean value of evaluation $\mathrm{q} 6 \mathrm{~h}$

${ }^{\mathrm{c}}$ mean value of the morning and evening evaluation

$\mathrm{N}$ = gut motility within normal limits

sl.decr. $=$ slightly decreased gut motility

sev.decr. = severely decreased gut motility

$1=$ horse received additional $100 \mathrm{mg}$ xylazine IV

${ }^{2}=$ horse received additional $1.1 \mathrm{mg} / \mathrm{kg}$ flunixin meglumine $\mathrm{qd}, 22,000 \mathrm{U} / \mathrm{kg}$ procaine penicillin $\mathrm{BID}$

${ }^{3}=$ horse received additional 0.5 to $1.1 \mathrm{mg} / \mathrm{kg}$ flunixin meglumine qd
} 
Table 8-12: Preoperative and postoperative appetite of the experimental horses

\begin{tabular}{|c|c|c|c|c|c|c|}
\hline \multirow[b]{2}{*}{ Appetite } & \multicolumn{6}{|c|}{ Mare no. } \\
\hline & 1 & 2 & 3 & 4 & 5 & 6 \\
\hline Preoperative & no feed & no feed & no feed & no feed & no feed & no feed \\
\hline $\begin{array}{l}1^{\text {st }}-8^{\text {th }} h \\
\text { post op }\end{array}$ & good & decr. $^{1}$ & $\mathrm{~N} / \mathrm{A}$ & decr. & good & good \\
\hline $1^{\text {st }} d$ post op. ${ }^{b}$ & good & good & $\mathrm{N} / \mathrm{A}$ & decr. & good & good \\
\hline $2^{\text {nd }} d$ post op. ${ }^{c}$ & good & good & $\mathrm{N} / \mathrm{A}$ & decr. & good & decr. \\
\hline 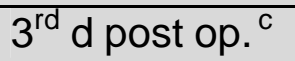 & good & good & $N / A$ & decr. & good & decr. $^{3}$ \\
\hline $4^{\text {th }}$ d post op. ${ }^{c}$ & good & good & $\mathrm{N} / \mathrm{A}$ & decr. & good & $\operatorname{good}^{3}$ \\
\hline $5^{\text {th }}$ d post op. ${ }^{c}$ & good & good & $\mathrm{N} / \mathrm{A}$ & decr. $^{2}$ & good & $\operatorname{good}^{3}$ \\
\hline $6^{\text {th }}$ d post op. ${ }^{c}$ & good & good & $\mathrm{N} / \mathrm{A}$ & decr. $^{2}$ & good & good \\
\hline $7^{\text {th }}$ d post op. ${ }^{c}$ & good & good & $\mathrm{N} / \mathrm{A}$ & decr. $^{2}$ & good & good \\
\hline $8^{\text {th }} \mathrm{d}$ post op. & good & good & $\mathrm{N} / \mathrm{A}$ & decr. $^{2}$ & good & good \\
\hline $9^{\text {th }}$ d post op. & good & good & $\mathrm{N} / \mathrm{A}$ & decr. $^{2}$ & good & good \\
\hline $10^{\text {th }} \mathrm{d}$ post op. & good & good & $\mathrm{N} / \mathrm{A}$ & decr. $^{2}$ & good & good \\
\hline $11^{\text {th }} \mathrm{d}$ post op. & good & good & $\mathrm{N} / \mathrm{A}$ & decr. $^{2}$ & good & good \\
\hline $12^{\text {th }} \mathrm{d}$ post op. & good & good & $\mathrm{N} / \mathrm{A}$ & $\mathrm{N} / \mathrm{A}$ & good & good \\
\hline $13^{\text {th }} \mathrm{d}$ post op. & good & good & $\mathrm{N} / \mathrm{A}$ & $\mathrm{N} / \mathrm{A}$ & good & good \\
\hline $14^{\text {th }} \mathrm{d}$ post op. & good & good & $\mathrm{N} / \mathrm{A}$ & $\mathrm{N} / \mathrm{A}$ & good & good \\
\hline
\end{tabular}

\footnotetext{
${ }^{\mathrm{a}}$ mean value of hourly evaluation

${ }^{\mathrm{b}}$ mean value of evaluation $\mathrm{q} 6 \mathrm{~h}$

${ }^{c}$ mean value of the morning and evening evaluation

good $=$ normal appetite

decr. $=$ decreased appetite

$1=$ horse received additional $100 \mathrm{mg}$ xylazine IV

${ }^{2}=$ horse received additional $1.1 \mathrm{mg} / \mathrm{kg}$ flunixin meglumine $\mathrm{qd}, 22,000 \mathrm{U} / \mathrm{kg}$ procaine penicillin BID

${ }^{3}=$ horse received additional 0.5 to $1.1 \mathrm{mg} / \mathrm{kg}$ flunixin meglumine qd
} 
Table 8-13: Preoperative and postoperative packed cell volume and total protein values of the experimental horses

\begin{tabular}{|c|c|c|c|c|c|c|}
\hline \multirow[b]{2}{*}{ PCV (in \%) } & \multicolumn{6}{|c|}{ Mare no. } \\
\hline & 1 & 2 & 3 & 4 & 5 & 6 \\
\hline Preoperative value & 39 & 49 & 35 & 38 & 45 & 48 \\
\hline Postoperative value & 35 & $\mathrm{~N} / \mathrm{E}$ & $\mathrm{N} / \mathrm{A}$ & $\mathrm{N} / \mathrm{E}$ & 38 & 38 \\
\hline $1^{\text {st }}$ d post op. am & 31 & $\mathrm{~N} / \mathrm{E}$ & $\mathrm{N} / \mathrm{A}$ & 35 & 40 & 35 \\
\hline $1^{\text {st }}$ d post op. pm & 28 & 30 & N/A & 34 & 33 & 33 \\
\hline $2^{\text {nd }} d$ post op. am & 26 & $\mathrm{~N} / \mathrm{E}$ & $\mathrm{N} / \mathrm{A}$ & 31 & 30 & 37 \\
\hline $2^{\text {nd }} d$ post op. pm & 29 & 35 & N/A & 20 & 33 & 34 \\
\hline \multicolumn{7}{|l|}{ TP (in g/dl) } \\
\hline Preoperative value & 6.5 & 7.4 & 7.1 & 5.4 & 7.3 & 6.8 \\
\hline Postoperative value & 5.8 & $\mathrm{~N} / \mathrm{E}$ & $\mathrm{N} / \mathrm{A}$ & $\mathrm{N} / \mathrm{E}$ & 6.8 & 5.1 \\
\hline $1^{\text {st }}$ d post op. am & 5.4 & $\mathrm{~N} / \mathrm{E}$ & $\mathrm{N} / \mathrm{A}$ & 4.2 & 6.6 & 5.8 \\
\hline $1^{\text {st }}$ d post op. pm & 6.1 & 6.5 & $\mathrm{~N} / \mathrm{A}$ & 4.9 & 6.8 & 5.1 \\
\hline $2^{\text {nd }} d$ post op. am & 6.4 & $\mathrm{~N} / \mathrm{E}$ & $\mathrm{N} / \mathrm{A}$ & 4.7 & 6.8 & 6.4 \\
\hline $2^{\text {nd }} d$ post op. pm & 6.4 & 6.5 & $\mathrm{~N} / \mathrm{A}$ & 5.0 & 6.9 & 6.7 \\
\hline
\end{tabular}

$\mathrm{N} / \mathrm{E}=$ not examined

am $=$ morning evaluation

$\mathrm{pm}=$ evening evaluation 
Table 8-14: Macroscopic post mortem findings of the experimental horses

\begin{tabular}{|c|c|c|}
\hline $\begin{array}{c}\text { Mare } \\
\text { no. }\end{array}$ & Skin & Subcutaneous tissue \\
\hline 1 & $\begin{array}{l}\text { tight seal, minimal black debris/sebum outside } \\
\text { laparotomy incision }\end{array}$ & $\begin{array}{l}\text { red/brown discoloration around umbilical laparoscopy } \\
\text { portal }\end{array}$ \\
\hline 2 & $\begin{array}{l}\text { tight seal, minimal black debris/sebum outside } \\
\text { laparotomy incision }\end{array}$ & $\begin{array}{l}\text { red/brown discoloration around both ovarian } \\
\text { laparoscopy portals }\end{array}$ \\
\hline 3 & $\mathrm{~N} / \mathrm{A}$ & $N / A$ \\
\hline 4 & $\begin{array}{l}\text { tight seal, minimal black debris/sebum outside } \\
\text { laparotomy incision }\end{array}$ & slight edema along ventral abdomen \\
\hline 5 & $\begin{array}{l}\text { tight seal, minimal black debris/sebum outside } \\
\text { laparotomy incision }\end{array}$ & NAF \\
\hline 6 & purulent material along laparotomy incision & $\begin{array}{l}\text { purulent material at laparotomy incision, } \\
\text { slight edema along ventral abdomen }\end{array}$ \\
\hline
\end{tabular}

\begin{tabular}{|c|c|c|}
\hline $\begin{array}{l}\text { Mare } \\
\text { no. }\end{array}$ & Abdominal fluid & Peritoneum \\
\hline 1 & NAF & $\begin{array}{l}\text { ventrolateral to left broad ligament remnant, } 5 \times 5 \mathrm{~cm} \\
\text { area covered with thin layer of fibrous tissue, no } \\
\text { adhesions }\end{array}$ \\
\hline 2 & NAF & NAF \\
\hline 3 & $\mathrm{~N} / \mathrm{A}$ & $\mathrm{N} / \mathrm{A}$ \\
\hline 4 & $\begin{array}{l}\text { increased amount of red/brown discolored abdominal } \\
\text { fluid }\end{array}$ & $\begin{array}{l}\text { moderate, subacute generalized peritonitis, } \\
\text { no increase of inflammation in caudal abdomen }\end{array}$ \\
\hline 5 & NAF & NAF \\
\hline 6 & NAF & $\begin{array}{l}\text { multiple, small fibrous tags on the serosa of cecum and } \\
\text { ascending colon ( } 1-2 \mathrm{~cm} \text { length), } \\
\text { fibrous adhesion between antimesenteric band of } \\
\text { descending colon ( } 10 \mathrm{~cm} \text { diameter), its mesocolon and } \\
\text { abdominal incision }\end{array}$ \\
\hline
\end{tabular}


Table 8-14 cont.: Macroscopic post mortem findings of the experimental horses

\begin{tabular}{|c|c|c|}
\hline $\begin{array}{l}\text { Mare } \\
\text { no. }\end{array}$ & $\begin{array}{l}\text { Left ovarian pedicle remnant and mesometrial } \\
\text { remnant }\end{array}$ & $\begin{array}{l}\text { Right ovarian pedicle remnant and mesometrial } \\
\text { remnant }\end{array}$ \\
\hline 1 & $\begin{array}{l}\text { ovarian pedicle remnant } \\
\text { - } \quad \text { smooth, } 1 \mathrm{~mm} \text { layer of tan/pink fibrous tissue } \\
\text { covering stapling line, staples not visible } \\
\text { mesometrial remnant } \\
\text { - cranial 1/3: smooth, } 1 \mathrm{~mm} \text { layer of tan/pink fibrous } \\
\text { tissue covering incision line; slight thickening (5-10 } \\
\text { mm) and slight brown discoloration where the } \\
\text { vessels had been, caudal } 2 / 3 \text { : NAF }\end{array}$ & $\begin{array}{l}\text { ovarian pedicle remnant } \\
\text { - } \quad \text { smooth, } 1 \mathrm{~mm} \text { layer of tan/pink fibrous tissue } \\
\text { covering stapling line, } 1 \text { staple barely visible } \\
\text { mesometrial remnant } \\
\text { - cranial 1/3: smooth, } 1 \mathrm{~mm} \text { layer of tan/pink fibrous } \\
\text { tissue covering incision line; slight thickening (5-10 } \\
\text { mm) and slight brown discoloration where the } \\
\text { vessels had been, caudal } 2 / 3 \text { : NAF }\end{array}$ \\
\hline 2 & $\begin{array}{l}\text { ovarian pedicle remnant } \\
-\quad \text { smooth, } 1 \mathrm{~mm} \text { layer of tan/pink fibrous tissue } \\
\text { covering stapling line, } 1 \text { staple barely visible } \\
\text { mesometrial remnant } \\
-\quad \text { cranial } 1 / 3 \text { : smooth, } 1 \mathrm{~mm} \text { layer of tan/pink fibrous } \\
\text { tissue covering incision line; slight thickening (5-10 } \\
\mathrm{mm} \text { ) and slight brown discoloration where the } \\
\text { vessels had been, caudal } 2 / 3 \text { : NAF }\end{array}$ & $\begin{array}{l}\text { ovarian pedicle remnant } \\
-\quad \text { smooth, } 1 \mathrm{~mm} \text { layer of tan/pink fibrous tissue } \\
\text { covering stapling line, } 1 \text { staple barely visible } \\
\text { mesometrial remnant } \\
-\quad \text { cranial } 1 / 3 \text { : smooth, } 1 \mathrm{~mm} \text { layer of tan/pink fibrous } \\
\text { tissue covering incision line; obvious thickening and } \\
\text { slight brown discoloration where the vessels had } \\
\text { been, } 3 \text { fibrous covered staples visible, caudal } 2 / 3 \text { : } \\
\text { NAF }\end{array}$ \\
\hline 3 & $\mathrm{~N} / \mathrm{A}$ & $\mathrm{N} / \mathrm{A}$ \\
\hline 4 & $\begin{array}{l}\text { ovarian pedicle remnant } \\
\text { - } \quad \text { smooth, } 1 \mathrm{~mm} \text { layer of tan/pink fibrous tissue } \\
\text { covering stapling line, no staples visible } \\
\text { mesometrial remnant } \\
\text { - cranial 1/3: smooth, } 1 \mathrm{~mm} \text { layer of tan/pink fibrous } \\
\text { tissue covering incision line; slight thickening (5-10 } \\
\text { mm) and slight brown discoloration where the } \\
\text { vessels had been, caudal } 2 / 3 \text { : NAF }\end{array}$ & $\begin{array}{l}\text { ovarian pedicle remnant } \\
\text { - } \quad \text { smooth, } 1 \mathrm{~mm} \text { layer of tan/pink fibrous tissue } \\
\text { covering stapling line, no staples visible } \\
\text { mesometrial remnant } \\
\text { - cranial } 1 / 3 \text { : smooth, } 1 \mathrm{~mm} \text { layer of tan/pink fibrous } \\
\text { tissue covering incision line; slight thickening (5-10 } \\
\text { mm) and slight brown discoloration where the } \\
\text { vessels had been, caudal } 2 / 3 \text { : NAF }\end{array}$ \\
\hline
\end{tabular}


Table 8-14 cont.: Macroscopic post mortem findings of the experimental horses

\begin{tabular}{|c|c|c|}
\hline $\begin{array}{c}\text { Mare } \\
\text { no. }\end{array}$ & $\begin{array}{l}\text { Left ovarian pedicle remnant and mesometrial } \\
\text { remnant }\end{array}$ & $\begin{array}{l}\text { Right ovarian pedicle remnant and mesometrial } \\
\text { remnant }\end{array}$ \\
\hline 5 & $\begin{array}{l}\text { ovarian pedicle remnant } \\
-\quad \text { smooth, } 1 \mathrm{~mm} \text { layer of tan/pink fibrous tissue } \\
\text { covering stapling line, no staples visible } \\
\text { mesometrial remnant } \\
-\quad \text { cranial 1/3: smooth, } 1 \mathrm{~mm} \text { layer of tan/pink fibrous } \\
\quad \text { tissue covering incision line; obvious firm, thickening } \\
\quad(2 \times 6 \mathrm{~cm}) \text { and slight brown discoloration where the } \\
\text { vessels had been, caudal } 2 / 3 \text { : NAF }\end{array}$ & $\begin{array}{l}\text { ovarian pedicle remnant } \\
-\quad \text { smooth, } 1 \mathrm{~mm} \text { layer of tan/pink fibrous tissue } \\
\text { covering stapling line, no staples visible } \\
\text { mesometrial remnant } \\
\text { - } \quad \text { cranial } 1 / 3 \text { : smooth, } 1 \mathrm{~mm} \text { layer of tan/pink fibrous } \\
\text { tissue covering incision line; slight thickening (5-10 } \\
\text { mm) and slight brown discoloration where the } \\
\text { vessels had been, seroma formation between the } 2 \\
\text { mesometrial layers, caudal } 2 / 3 \text { : NAF }\end{array}$ \\
\hline 6 & $\begin{array}{l}\text { ovarian pedicle remnant } \\
-\quad \text { smooth, } 1 \mathrm{~mm} \text { layer of tan/pink fibrous tissue } \\
\text { covering stapling line } \\
\text { mesometrial remnant } \\
\text { - cranial } 1 / 3 \text { : smooth, } 1 \mathrm{~mm} \text { layer of tan/pink fibrous } \\
\text { tissue covering incision line; slight thickening (5-10 } \\
\text { mm) and slight brown discoloration where the } \\
\text { vessels had been, caudal 2/3: NAF }\end{array}$ & $\begin{array}{l}\text { ovarian pedicle remnant } \\
-\quad \text { smooth, } 1 \mathrm{~mm} \text { layer of tan/pink fibrous tissue } \\
\text { covering stapling line, no staples visible } \\
\text { mesometrial remnant } \\
\text { - cranial 1/3: smooth, } 1 \mathrm{~mm} \text { layer of tan/pink fibrous } \\
\text { tissue covering incision line; slight thickening (5-10 } \\
\text { mm) and slight brown discoloration where the } \\
\text { vessels had been, caudal 2/3: NAF }\end{array}$ \\
\hline
\end{tabular}


Table 8-14 cont.: Macroscopic post mortem findings of the experimental horses

\begin{tabular}{|c|l|l|}
\hline $\begin{array}{c}\text { Mare } \\
\text { no. }\end{array}$ & Uterine stump & Bladder / other abnormal findings \\
\hline $\mathbf{1}$ & $\begin{array}{l}\text { smooth, <1 mm layer of tan/pink fibrous tissue } \\
\text { covering suture line; suture knots barely visible }\end{array}$ & NAF \\
\hline $\mathbf{2}$ & $\begin{array}{l}\text { smooth, < } 1 \mathrm{~mm} \text { layer of tan/pink fibrous tissue } \\
\text { covering suture line; suture knots barely visible }\end{array}$ & NAF \\
\hline $\mathbf{3}$ & N/A & bilateral, comminuted femur fracture \\
\hline $\mathbf{4}$ & $\begin{array}{l}\text { smooth, <1 mm layer of tan/pink fibrous tissue } \\
\text { covering suture line; no suture knots visible }\end{array}$ & $\begin{array}{l}\text { NAF on bladder, } \\
\text { severe locally extensive, acute to subacute } \\
\text { pleuropneumonia }\end{array}$ \\
\hline $\mathbf{5}$ & $\begin{array}{l}\text { smooth, <1 mm layer of tan/pink fibrous tissue } \\
\text { covering suture line; no suture knots visible }\end{array}$ & NAF \\
\hline $\mathbf{6}$ & $\begin{array}{l}\text { smooth, < } 1 \mathrm{~mm} \text { layer of tan/pink fibrous tissue } \\
\text { covering suture line; no suture knots visible }\end{array}$ & NAF \\
\hline
\end{tabular}




\section{Vita}

Uta Delling was born in Karl-Marx-Stadt (renamed Chemnitz), Germany. She attended the Faculty of Veterinary Medicine at the University of Leipzig.

Following she pursued a research project at the Large Animal Surgery Clinic leading to a Dr.med.vet. degree. During that time she was funded by a scholarship from the federal state of Saxony.

In 2000 she was accepted into an Internship at the Department of Veterinary Internal Medicine, Western College of Veterinary Medicine, University of Saskatchewan and continued with an Internship at the Department of Large Animal Surgery, Western College of Veterinary Medicine, University of Saskatchewan.

In 2001, she started her Large Animal Surgery Residency in combination with a Master of Science Program at the Department of Large Animal Clinical Sciences at the VirginiaMaryland Regional College of Veterinary Medicine.

In 2005 she passed the certifying examination of the American College of Veterinary Surgeons. 